\title{
A New Family of Doubly Cyclopalladated Diimines. A Remarkable Effect of the Linker between the Metalated Units on Their Cytotoxicity
}

\author{
Joan Albert, ${ }^{*}{ }^{\dagger}$ Ramon Bosque, ${ }^{\dagger}$ Magali Cadena,${ }^{\dagger}$ Lucía D’Andrea, ${ }^{\dagger}$ Jaume Granell,,${ }^{*} \dagger$ Asensio \\ González, ${ }^{\ddagger}$ Josefina Quirante, ${ }^{\ddagger}$ Carmen Calvis,${ }^{\perp}$ Ramon Messeguer,${ }^{\S}$ Josefa Badía ${ }^{\prime \prime}$ Laura Baldomà,\|

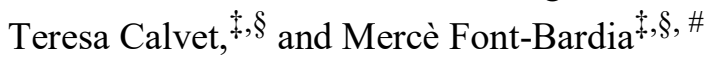

$†$ Departament de Química Inorgànica i Institut de Biomedicina (IBUB), Facultat de Química,

Universitat de Barcelona, Martí i

Franquès 1-11, E-08028 Barcelona, Spain

†Laboratori de Química Orgànica, Facultat de Farmàcia, Universitat de Barcelona, Avenida Joan XXIII s/n, E-08028 Barcelona, Spain

§Biomed Division LEITAT Technological Center, Parc Científic, Edifici Hèlix, C/ Baldiri Reixach, 1521, E-08028 Barcelona, Spain

\|Departament de Bioquímica i Biología Molecular, Facultat de Farmàcia, Universitat de Barcelona, Avenida Joan XXIII s/n, E-08028 Barcelona, Spain

$\perp$ Unitat de Difraccióde Raigs-X, Centre Científic i Tecnològic, Universitat de Barcelona, Soléi Sabaris 1-3, E-08028 Barcelona, Spain

\#Departament de Cristal·lografia, Mineralogia i Dipòsits Minerals, Facultat de Geologia, Universitat de Barcelona, Martí i Franquès s/n, E-08028 Barcelona, Spain 
41 The cyclopalladation of a series of symmetric diimines with the formula $(\mathrm{RC} 6 \mathrm{H} 4 \mathrm{CH} \bigoplus \mathrm{NZ}) 2$, where $\mathrm{Z}=$

$42 \mathrm{CH} 2$ or $(\mathrm{CH} 2) 2 \mathrm{OCH} 2$ and $\mathrm{R}=\mathrm{p}-\mathrm{Cl}, \mathrm{p}-\mathrm{OMe}, \mathrm{p}-\mathrm{NO} 2$, and $\mathrm{o}-\mathrm{Cl}$, is described. Optimal conditions to

43 obtain the dimetalated compounds were found to be palladium(II) acetate, in toluene, at $60^{\circ} \mathrm{C}$ and with

44 a reaction time of 2-4 h. The reactivity of the dimetalated compounds with monodentate, bidentate, and bis(monodentate) Lewis bases was also studied. The cytotoxic activity of some selected compounds was evaluated against a panel of adenocarcinoma cell lines (colon HCT116 and breast MCF7 and MDA$\mathrm{MB} 231$ ). Compounds containing the fragment $\mathrm{NCH} 2 \mathrm{CH} 2 \mathrm{OCH} 2 \mathrm{CH} 2 \mathrm{OCH} 2 \mathrm{CH} 2 \mathrm{~N}$ exhibited a remarkable cytotoxic activity in the three cancer cells assayed, but complexes containing the $\mathrm{NCH} 2 \mathrm{CH} 2 \mathrm{~N}$ fragment showed no activity. It seems that the length and flexibility of the central saturated chain in the imine molecule, as well as its lipophilicity and hydrophilicity, explain the different

51 cytotoxicity of the two series of coordination compounds here reported.

52<smiles>[R]c1ccc2c(c1)[P+](C)(C)N(CC([Y])(C)C)C2</smiles>

No cytotoxic activity<smiles>[R]c1cccc2c1[R](C)(C)N(CCOCC(F)(F)F)C2</smiles>

Remarkable cytotoxic activity 
The cyclometalation reaction is a well-known process that represents one of the classic ways to activate $\mathrm{C}-\mathrm{H}$ bonds in heterosubstituted organic molecules. 1 The first cyclometalated compounds were reported in the mid 1960s, 2 and since then, this reaction has extensively been studied and has gained a great interest given the application of metallacycles in many areas, which include organic synthesis, catalysis, design of metallomesogens, asymmetric synthesis, resolution of racemic ligands, $\mathrm{C}-\mathrm{H}$ bond activation, or in the synthesis and reactivity of organometallic complexes with biologically relevant ligands. 3

The use of cyclopalladated compounds as antitumor drugs is one of the most interesting applications of these derivatives. It has been postulated that these compounds can be an alternative to platinum-based drugs, owing to the similar chemistry between palladium and platinum.4 Palladium complexes show a higher kinetic lability that can be modulated by means of the use of chelating ligands such as cyclometalated organic derivatives. Recently, a considerable number of palladacycles have been evaluated for cytotoxic activity against a variety of cancer cell lines with remarkable results. 5

For biological activity, an important factor in the design of metal-containing anticancer agents is to provide an optimal balance between lipophilicity and reactivity. The lipophilicity of a drug candidate, which can be tuned with the appropriate choice of functional groups, is important because it dictates the degree of cellular uptake, whereas optimal reactivity kinetics ensure that a significant amount of metal can bind to DNA or other cellular targets within the biologically relevant time frame.

Studies on platinum(II) compounds show that their activity relies mostly on specific interactions with DNA, leading to damage and ultimately to cell death. Previous to the metal-DNA adduct formation, the departing ligands (generally a halide leaving group) play an integral role in influencing the aquation rate, therefore improving aqueous solubility or hydrolytic stability of the complex inside the cell.

It has been proposed that polymetallic complexes can present a stronger electrostatic recognition of DNA, in comparison with monomeric species, due to the fact that polynuclear species are generally highly positively charged in solution. The compound [ $\{$ trans-PtCl (NH3)2 $\} 2$ - ( $\mu$-trans - $\{\mathrm{Pt}-$ (NH3)2(NH2(CH2)6NH2)2\}) ]4+ (BBR3464) is a trinuclear platinum drug highly cytotoxic both in vitro and in vivo (see Chart 1), and its activity derives from the flexible adducts that form with DNA. This compound completed a phase I trial, but failed phase II probably due to instability in blood and rapid drug degradation in vivo.6 Recently a new family of dinuclear platinum(II) complexes containing bispyridyl-based ligands has been described, and its cytotoxicity was determined against the human ovarian carcinoma cell line A2780.7

Cyclometalation involves the coordination of one metal atom per organic ligand in the majority of cases. However, a relatively large number of doubly cyclometalated compounds derived from diamines, diimines, bis(oximes), bis(hydrazones), azobenzenes, bis(iminophosphoranes), azines, pyrazines, bis(pyrimidines), bis(pyridines), bis(pyrazoles), and bis-(imidazoles) are known. 8

Here we describe the cyclopalladation of a series of symmetric diimines with the formula $(\mathrm{RC} 6 \mathrm{H} 4 \mathrm{CH}=\mathrm{NZ}) 2$, where $\mathrm{Z}=\mathrm{CH} 2$ or $(\mathrm{CH} 2) 2 \mathrm{OCH} 2)$, with the aim of obtaining dipalladated compounds containing the fragment $\mathrm{NCH} 2 \mathrm{CH} 2 \mathrm{~N}$ or $\mathrm{N}(\mathrm{CH} 2) 2 \mathrm{O}(\mathrm{CH} 2) 2 \mathrm{O}(\mathrm{CH} 2) 2 \mathrm{~N}$, which exhibit differences in length, flexibility, lipophilicity, and hydrophilicity. The present paper also addresses the study of these new polynuclear compounds as antitumor agents. Additionally, electrophoretic DNA migration studies in the absence and in the presence of topoisomerase I have been performed, in order to gain insights into the biological behavior of the synthesized compounds. 
Synthesis of Compounds. The symmetric diimines ( $\mathrm{RC} 6 \mathrm{H} 4 \mathrm{CH}=\mathrm{NZ}) 2[\mathrm{Z}=\mathrm{CH} 2, \mathrm{R}=\mathrm{p}-\mathrm{Cl}(1), \mathrm{p}-\mathrm{OMe}$ combining the appropriate, aldehyde and symmetric diamine in a 2:1 molar ratio, following the previously described procedures.9 The $1 \mathrm{H}$ and $13 \mathrm{C}\{1 \mathrm{H}\}$ NMR spectra of diimines 1-6 exhibited only one set of signals, which was attributed to the (E,E) isomer, as confirmed by $1 \mathrm{H}-1 \mathrm{H}$ NOESY experiments. The cyclometalation of ligands $1-6$ can produce mono- or dicyclopalladated compounds by $\mathrm{C}-\mathrm{H}$ activation. Therefore, some studies on the cyclometalation of diimine 1 were conducted, in order to optimize the preparation of the dimetalated derivative 1a. Solvent screening (toluene, acetone, glacial acetic acid, and chloroform) was performed at different temperatures and reaction times. Synthesis in acetic acid and chloroform led to the dimetalated derivative 1a with modest yields due to the formation of significant amounts of the monometalated complex. Optimal conditions to obtain the dimetalated compound $1 \mathrm{a}$ were found to be in toluene, at $60^{\circ} \mathrm{C}$, and with a reaction time of $2-4 \mathrm{~h}$, using palladium(II) acetate as a metalating agent. When these conditions were applied to the diimines 2 and 3 , the acetato-bridging dimetalated compounds $2 \mathrm{a}$ and $3 \mathrm{a}$ were also prepared through double intramolecular $\sigma(\mathrm{Csp} 2-\mathrm{H})$ bond activation (see Scheme 1). Compounds $4 \mathrm{a}$, 5a, and 6a were obtained using acetic acid as solvent (see Scheme 1 and Experimental Part). Compounds 1a-3a and 4a-6a were obtained in $77-55 \%$ and $40-31 \%$ yield, respectively (see Experimental Part and Supporting Information).

All attempts to metalate ligands (p-NO2-C6H4CH=NCH2) 2 and (o-Cl-C6H4CH=NCH2) 2 failed. The main problem seems to be the hydrolysis of these ligands. In some cases the formation of complexes such as $[\mathrm{Pd}(\mathrm{en}) 2] 2+$ and $[\mathrm{Pd}(\mathrm{en})-(\mathrm{OAc})]+$ was detected by mass spectrometry, suggesting that the formation of these species makes the hydrolysis of these diimines easier.

Acetato-bridged derivatives 1a-6a were characterized by mass spectra, elemental analyses, and infrared spectra. The $1 \mathrm{H}$ and $13 \mathrm{C}\{1 \mathrm{H}\}$ NMR spectra of these compounds produced a complex pattern of uninterpretable signals, and these data are not included in the experimental part. This could be attributed to the lability of the acetato ligands, the cis-trans rearrangements of the complexes, or some equilibria involving species of different nuclearity. 10

Characterization of compounds $1 \mathrm{a}-6 \mathrm{a}$ in solution was conducted by analysis of their dinuclear derivatives obtained in an NMR tube by addition of pyridine-d5 to a $\mathrm{CDCl} 3$ solution of these compounds. This reaction afforded the expected dinuclear compounds $[\{\mathrm{Pd}(\mathrm{O} 2 \mathrm{CMe})(\mathrm{py}-$

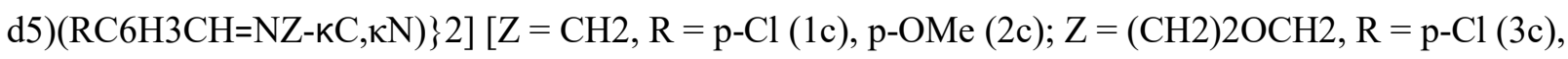
$\mathrm{p}-\mathrm{OMe}(4 \mathrm{c}), \mathrm{p}-\mathrm{NO} 2(5 \mathrm{c})$, and o-Cl (6c)]. The high-field shift of the aromatic protons of the palladated ring in the proton NMR spectra of compounds $\mathrm{c}$ indicates the cis disposition of the pyridine relative to the metalated carbon atom.11 Despite the simplification of the spectra when adding pyridine-d5 to a $\mathrm{CDCl} 3$ solution of the acetato-bridging compounds a, in some instances some minor species were observed by NMR spectra. These minor compounds are also dicyclometalated complexes, because in all cases the $\mathrm{H} 2$ aromatic proton appears high-field shifted at $\delta=6.0-6.2 \mathrm{ppm}$.

The MALDI TOF $(+)$ mass spectra of 1a-6a led to the dinuclear monocation [M1 - AcO]+, where M1 corresponds to one dimetalated moiety in which the two palladium atoms are linked by two acetato bridging ligands. The tetrapalladated fragment $[\mathrm{M} 2-\mathrm{AcO}]+$, where $\mathrm{M} 2$ designates two dimetalated moieties bound by four acetato bridging ligands, was observed only for the acetato-bridged complexes 1a and 2a. However, the possibility of the bridged complexes being polymeric in the solid state cannot be ruled out, as the aforementioned peaks may arise from fragmentation of a polymeric structure. 
The cyclopalladated compounds $1 \mathrm{a}-6 \mathrm{a}$ were easily converted by a metathesis reaction with $\mathrm{LiCl}$ into the chloridobridged cyclopalladated analogues $1 \mathrm{~b}-6 \mathrm{~b}$. These chloridobridged derivatives were characterized by mass spectra and infrared spectra. The MALDI TOF $(+)$ mass spectra of $1 \mathrm{~b}$ and $2 \mathrm{~b}$ revealed the tetrapalladated monocation $[\mathrm{M} 2-\mathrm{Cl}]+$. Nevertheless, the polynuclear nature of these complexes cannot be discarded. These new compounds were very insoluble in common solvents, which precluded their purification by recrystallization or column chromatography. Unlike their acetato-bridged counterparts, $1 \mathrm{H}$ NMR spectra of a chloroform-d solution of the chlorido-bridged derivatives in the presence of an excess of py-d5 showed just one compound with the formula $[\{\mathrm{Pd}(\mathrm{Cl})(\mathrm{py}-\mathrm{d} 5)(\mathrm{RC} 6 \mathrm{H} 3 \mathrm{CH}=\mathrm{NZ}-$ $\kappa \mathrm{C}, \kappa \mathrm{N})\} 2][\mathrm{Z}=\mathrm{CH} 2, \mathrm{R}=\mathrm{p}-\mathrm{Cl}(1 \mathrm{~d}), \mathrm{p}-\mathrm{OMe}(2 \mathrm{~d}) ; \mathrm{Z}=(\mathrm{CH} 2) 2 \mathrm{OCH} 2, \mathrm{R}=\mathrm{p}-\mathrm{Cl}(3 \mathrm{~d}), \mathrm{p}-\mathrm{OMe}(4 \mathrm{~d}), \mathrm{p}-$ $\mathrm{NO} 2(5 \mathrm{~d})$, and o- $\mathrm{Cl}(6 \mathrm{~d})]$. The different behavior of chlorido- and acetato-bridged compounds versus pyridine can be related with the higher lability of acetate ligands.

Suitable crystals for X-ray analysis of $1 \mathrm{~d} \cdot 3(\mathrm{CDCl} 3)$ and $2 \mathrm{~d} \cdot 2(\mathrm{CDCl} 3)$ were obtained by slow evaporation of deuterated chloroform solutions of $1 b$ or $2 b$ in the presence of an excess of deuterated pyridine-d5. Both structures present a dicyclopalladated unit containing a dianionic bis-[C,N] chelating ligand. The coordination sphere of each palladium atom is completed by one chlorido ligand plus one deuterated pyridine molecule in the cis position relative to the metalated carbon. The metal center exhibits a slightly distorted square-planar geometry owing to the $\mathrm{C}-\mathrm{Pd}-\mathrm{N}$ bite angle, and the palladacycle is nearly coplanar with the phenyl metalated ring. The bond distances and bond angles of the metallacycle are similar to those reported for related complexes. 12 Due to steric reasons, the pyridine ring is orientated at dihedral angles of $60-90^{\circ}$ with respect to the metalated phenyl ring. The $\mathrm{NCH} 2 \mathrm{CH} 2 \mathrm{~N}$ framework shows a zigzag arrangement with $\mathrm{N}-\mathrm{C}-\mathrm{C}-\mathrm{N}$ torsion angles close to $180^{\circ}$, and the palladacycles are practically parallel.

The structures of the two compounds reveal diverse intermolecular interactions. The crystal packing of $1 \mathrm{~d}$ shows chains that propagate along the [110] vector, which are consolidated by $\pi-\pi$ interactions between each palladacycle and its neighboring phenyl metalated ring. The crystal packing of complex $2 \mathrm{~d}$ is stabilized by $\mathrm{C}-\mathrm{H} \cdots \pi$ weak intermolecular interactions generating a chain along the crystallographic a axis.

Halido-bridged complexes $1 \mathrm{~b}-6 \mathrm{~b}$ could be cleanly converted to dinuclear compounds $[\{\mathrm{Pd}(\mathrm{Cl})(\mathrm{PPh} 3)(\mathrm{RC} 6 \mathrm{H} 3 \mathrm{CH}=\mathrm{NZ}-\mathrm{\kappa C}, \kappa \mathrm{N})\} 2][\mathrm{Z}=\mathrm{CH} 2, \mathrm{R}=\mathrm{p}-\mathrm{Cl}(1 \mathrm{e}), \mathrm{p}-\mathrm{OMe}(2 \mathrm{e}) ; \mathrm{Z}=(\mathrm{CH} 2) 2 \mathrm{OCH} 2$, $\mathrm{R}=\mathrm{p}-\mathrm{Cl}(3 \mathrm{e}), \mathrm{p}-\mathrm{OMe}(4 \mathrm{e}), \mathrm{p}-\mathrm{NO} 2$ (5e), and o-Cl (6e)] upon addition of triphenylphosphane in a $\mathrm{PPh} 3 /$ dicyclometalated unit molar ratio of 2:1. Cyclopalladated derivatives $1 \mathrm{e}-6 \mathrm{e}$ were characterized by mass spectra, elemental analysis, infrared spectra, and $1 \mathrm{H}, 13 \mathrm{C}\{1 \mathrm{H}\}$, and $31 \mathrm{P}\{1 \mathrm{H}\} \mathrm{NMR}$. The aromatic protons of the palladated ring appear to be high-field shifted in the proton NMR spectrum, showing the cis disposition between the phosphane and the metalated carbon.13

Suitable crystals for X-ray analysis of $1 \mathrm{e} \cdot 4(\mathrm{CDCl} 3)$ were obtained by slow evaporation of a deuterated chloroform solution of complex 1e. The distances between palladium and the coordinated atoms are similar to those reported.14 The phosphorus and nitrogen atoms adopt a trans arrangement, the metal center exhibits a slightly distorted square-planar geometry owing to the $\mathrm{C}-\mathrm{Pd}-\mathrm{N}$ bite angle, and the palladacycle is nearly coplanar with the phenyl metalated ring. The palladium-nitrogen bond distance is in the range 2.099-2.133 $\AA$. In contrast, the palladium-iminic nitrogen bond in the pyridinecontaining derivatives is in the range 1.995-2.071 $\AA$, in agreement with the larger trans influence of triphenylphosphane.

The $\mathrm{NCH} 2 \mathrm{CH} 2 \mathrm{~N}$ framework in 1e shows a zigzag arrangement with $\mathrm{N}-\mathrm{C}-\mathrm{C}-\mathrm{N}$ torsion angles close to $180^{\circ}$, and the palladacycles are practically parallel. As shown in complex $2 \mathrm{~d}$ the crystal packing in $1 \mathrm{e}$ is stabilized by $\mathrm{C}-\mathrm{H} \cdots \pi$ interactions, generating a chain along the crystallographic a axis.

Reactivity of Compounds $1 \mathrm{~b}$ and $3 \mathrm{~b}$ toward Bidentate Lewis Bases. Considerable efforts were made to explore the reactivity of the chlorido-bridged complexes $1 \mathrm{~b}$ and $3 \mathrm{~b}$ with potentially bidentate and 
bis(monodentate) Lewis bases. The reactions of complex $1 \mathrm{~b}$ with a variety of rigid and flexible ligands, such as $\mathrm{NH} 2(\mathrm{CH} 2) 2 \mathrm{O}(\mathrm{CH} 2) 2 \mathrm{O}(\mathrm{CH} 2) 2 \mathrm{NH} 2$, trans-Ph2PCH=CHPPh2, NH2CH2(CHOH)CH2NH2, or 4,4'- bipyridine, were unsuccessful, as extremely insoluble solids were formed in all cases. The lack of solubility of these products suggested the possibility of a polymeric structure. Similar results were obtained when using the dicyclopalladated derivative $3 \mathrm{~b}$. However, one exception was found. Treatment of $3 \mathrm{~b}$ with the highly flexible ligand 2,2'-(ethylenedioxy)bis-(ethylamine) for $4 \mathrm{~h}$ at room temperature in chloroform afforded compound $3 \mathrm{f}$, which was characterized by mass spectra, infrared spectra, and $1 \mathrm{H}$ and $13 \mathrm{C}\{1 \mathrm{H}\}$ NMR spectra (see Chart 2).

In the $1 \mathrm{H}$ NMR spectra of $3 \mathrm{f}$, coordination of the Lewis base to the metal center caused deshielding of the aliphatic protons of the bridging ligand with respect to the free Lewis base. This fact was further supported by MS and IR spectra. In the mass spectra the dipalladated fragments $[\mathrm{M}-\mathrm{Cl}]+$ were detected, but there was no evidence of tetranuclear fragments or higher order aggregates. It should be noted that the $1 \mathrm{H}-1 \mathrm{H}$ NOESY spectrum of complex $3 \mathrm{f}$ revealed the existence of cross-peaks between the $\mathrm{CH} 7=\mathrm{N}$ proton and all the aliphatic protons of the adjacent $\mathrm{N}-\mathrm{CH} 2{ }_{8}-\mathrm{CH} 29-\mathrm{O}-\mathrm{CH} 210$ moiety. Similarly, the aromatic proton $\mathrm{H} 2$ showed correlations with all protons of the $\mathrm{NH} 2-\mathrm{CH} 211-\mathrm{CH} 2$ ${ }_{12-}-\mathrm{O}-\mathrm{CH} 213$ aliphatic chain. The fact that the imine proton is close in space to $\mathrm{CH} 210$, and $\mathrm{H} 2$ to $\mathrm{CH} 2$ 13, evidenced that the molecule adopts a somewhat folded conformation, which seems to fit with a dinuclear structure.

Theoretical calculations on the systems $[(\{\mathrm{Pd}(\mathrm{Cl})\{4-\mathrm{ClC} 6 \mathrm{H} 3 \mathrm{CH}=\mathrm{N}(\mathrm{CH} 2) 2 \mathrm{OCH} 2-\kappa \mathrm{C}, \kappa \mathrm{N}\}\} 2\{\mu-$ $\left.\left.\left.\mathrm{NH} 2(\mathrm{CH} 2) 2 \mathrm{O}-(\mathrm{CH} 2) 2 \mathrm{O}(\mathrm{CH} 2) 2 \mathrm{NH} 2-\mathrm{kN}^{2} \mathrm{kN}^{\prime}\right\}\right) \mathrm{n}\right](\mathrm{n}=1$ and 2$)$ were performed in order to provide complementary insights into structure $3 \mathrm{f}$. Molecular dynamics simulations led to the most stable conformations of the dinuclear and the tetranuclear forms ( $n=1$ and 2, respectively), which were then reoptimized at the DFT level. In accordance with 2D NMR studies, calculations revealed that both model systems adopt folded conformations. Optimized geometries for the dinuclear and tetranuclear forms are shown in Figures 4 and 5, respectively. Additionally, $\mathrm{H} \cdots \mathrm{H}$ distances between the imine proton and its adjacent aliphatic chain $\left(\mathrm{CH} 2{ }_{8-}-\mathrm{CH} 29-\mathrm{O}-\mathrm{CH} 210\right)$, as well as the $\mathrm{H} \cdots \mathrm{H}$ distances between the $\mathrm{H} 2$ atom and its neighboring $\mathrm{NH} 2-\mathrm{CH} 211-\mathrm{CH} 212-\mathrm{O}-\mathrm{CH} 213$ chain, are generally consistent with the accepted range of NOE interactions $(2-5 \AA)$.

DFT calculations predicted that in a vacuum at $0 \mathrm{~K}$ the tetranuclear form is slightly more stable, as the energy increment corresponding to the formation of the tetranuclear complex from two molecules of the dinuclear compound ( $\Delta$ Edimerization) is $-0.4 \mathrm{kcal} / \mathrm{mol}$. The addition of solvent effects increases the stability of the dinuclear form. Thus, in chloroform, $\Delta$ Edimerization is $+4.9 \mathrm{kcal} / \mathrm{mol}$. The large size of the tetranuclear system precluded us from making a frequency calculation; hence a comparison of free energies could not be made at the DFT level.

In order to make an estimation of $\Delta$ Gdimerization, we repeated the calculations using the PM6 semiempirical method, which gives $\Delta$ Edimerization values very close to DFT $(-0.6 \mathrm{kcal} / \mathrm{mol}$ in vacuum). The PM6 thermodynamic corrections result in a further stabilization of the dinuclear form. Thus, on combining the DFT energies with the semiempirical thermodynamic corrections, the resulting $\Delta$ Gdimerization is $17 \mathrm{kcal} / \mathrm{mol}$ in chloroform, although this value should be regarded as approximate.

In conclusion, theoretical and experimental evidence (mass spectrum and NOESY experiment) suggest that in solution compound $3 \mathrm{f}$ could adopt a folded dinuclear structure. 
241 Human colon (HCT116) and breast (MCF7 and MDAMB231) cancer cell lines were used to test the

242 cytotoxic activity of cyclometalated palladium(II) complexes derived from diimines 1 and 3 containing

243 the $\mathrm{NCH} 2 \mathrm{CH} 2 \mathrm{~N}$ and the $\mathrm{NCH} 2 \mathrm{CH} 2 \mathrm{OCH} 2 \mathrm{CH} 2 \mathrm{OCH} 2 \mathrm{CH} 2 \mathrm{~N}$ fragments, respectively. For comparison

purposes the free ligands 1 and 3 and cisplatin were evaluated under the same experimental conditions in the three cell lines selected. The IC50 values resulting from an average of two experiments are shown in Table 1 , and the effects of $3 a, 3 b, 3 e$, and $3 \mathrm{f}$ on the growth of the assayed cell lines are displayed in Figure 6.

248 No cytotoxic activity was observed either for the free ligands 1 and 3 or for the cyclopalladated complexes $1 \mathrm{a}, 1 \mathrm{~b}$, and $1 \mathrm{e}$, containing the $\mathrm{NCH} 2 \mathrm{CH} 2 \mathrm{~N}$ fragment.

Interestingly, the metalated palladium(II) complexes $3 \mathrm{a}, 3 \mathrm{~b}, 3 \mathrm{e}$, and $3 \mathrm{f}$ featuring the

$\mathrm{NCH} 2 \mathrm{CH} 2 \mathrm{OCH} 2 \mathrm{CH} 2 \mathrm{OCH} 2 \mathrm{CH} 2 \mathrm{~N}$ fragment exhibited a remarkable cytotoxic effectiveness in the three cellular lines assessed (Table 1), and most of these compounds exhibited lower IC50 values than that of cisplatin. The best inhibition of cell growth proliferation was provided for compounds $3 \mathrm{a}$ in HCT116 colon and MCF7 breast adenocarcinoma cell lines, while compound 3e was the most effective against MDA-MB231 breast cancer cells.

A great number of factors such as lipophilicity, stability in biological medium, molecular size, flexibility, and influx or efflux through cellular membranes may account for the different cytotoxicity of transition metal compounds. The dramatic increase in cytotoxicity observed for the compounds containing the fragment $\mathrm{NCH} 2 \mathrm{CH} 2 \mathrm{OCH} 2 \mathrm{CH} 2 \mathrm{OCH} 2 \mathrm{CH} 2 \mathrm{~N}$ upon the complexes bearing the $\mathrm{NCH} 2 \mathrm{CH} 2 \mathrm{~N}$ fragment in the three cancer cells assayed can be racionalized in terms of the flexibility, lipophilicity, and hydrophilicity provided by each fragment in the diimine ligand.

The influence of flexibility on the cytotoxicity of the complexes is in agreement with the proposal that polymetallic complexes derive their activity through the flexible adducts that they form with DNA.6 On the other hand, hydrophilicity can be related with hydrogen-bonding capability of the oxygenated fragments, which may favor solubility in the biological media as well as interactions with biomolecular targets. 15 Finally, the similarity in the IC50 values of compounds $3 a$ and $3 b$, contaning acetato- or chlorido-bridged ligands, can be understood if we consider that, in the biological media, these products may easily be transformed into the aqua cation $[\mathrm{Pd}(\mathrm{CN})(\mathrm{H} 2 \mathrm{O}) 2]+$, being $(\mathrm{CN})$ the cyclometalated imine. 16

Recently, it has been reported a high cellular uptake of structurally different palladium-coordinated compounds [thiosemicarbazone $\mathrm{Pd}(\mathrm{II})$ compounds, planaramine $\mathrm{Pd}(\mathrm{II})$ complexes, trinuclear $\mathrm{Pt}-\mathrm{Pd}-\mathrm{Pt}$ analogues of BBR3464, etc.) by several human cancer cell lines.17 In addition, it was found that within a series of complexes the highest cellular accumulation is in line with the highest cytotoxic activity. $17 \mathrm{a}, \mathrm{b}$

The binding of 1a, 1b, 1e, 3a, 3b, 3e, and 3f to DNA was studied by their ability to modify the electrophoretic mobility of the supercoiled closed circular (ccc) and the open circular (oc) forms of pBluescript $\mathrm{SK}+$ plasmid DNA. The ccc form usually moves faster due to its compact structure. Figure 7 shows the electrophoretic mobility of pBluescript SK + plasmid DNA incubated with the studied palladium(II) compounds at $37{ }^{\circ} \mathrm{C}$ in an unwinding experiment at increasing concentrations (from 2.5 to $200 \mu \mathrm{M}$ ). To provide a basis for comparison, incubation of DNA with cisplatin and ethidium bromide $(\mathrm{EtBr})$ was also performed using the same concentrations and conditions.

As expected, cisplatin greatly altered the electrophoretic mobility of pBluescript SK + plasmid DNA at $2.5 \mu \mathrm{M}$, but for EtBr only a very slight decrease in the electrophoretic mobility of DNA was detected at 25 to $100 \mu \mathrm{M}$ concentration. Organopalladium(II) compounds $1 \mathrm{a}, 1 \mathrm{~b}, 1 \mathrm{e}, 3 \mathrm{a}, 3 \mathrm{~b}, 3 \mathrm{e}$, and $3 \mathrm{f}$ were less 
efficient than cisplatin in removing the supercoils from DNA, although some were more cytotoxic than cisplatin itself. Hence, these results suggested that DNA might not be the exclusive target biomolecule for this kind of compound. 6

On increasing the concentration of $1 \mathrm{a}, 3 \mathrm{a}, 3 \mathrm{~b}$, and $3 \mathrm{f}$, a significant change in plasmid DNA mobility is detected. The migration rate of the supercoiled band decreased until it comigrated with the nicked relaxed band. In these titration experiments, the coalescence point (defined as the amount of palladium complex required for complete removal of all supercoils from DNA) occurred at $25 \mu \mathrm{M}$ (lane 5). Unwinding of negative supercoiled DNA to positive supercoiled DNA was observed in the electrophoretogram at higher concentrations for $1 \mathrm{a}$ (lanes 6 and 7) and for $3 a, 3 b$, and $3 f$ (lane 6 ). The DNA was destroyed and no longer visible18 at concentrations higher than $100 \mu \mathrm{M}$. The same effect of coalescence and positive supercoiling was observed for cisplatin (Figure 7, bottom). Interestingly, complex 3a, exhibiting lower IC50 values in HCT116 colon and MCF7 breast human adenocarcinoma cells, turned out to be one of the most efficient in retarding the plasmid DNA migration.

It is noteworthy that noncytotoxic cyclopalladated compounds (i.e., complexes $1 \mathrm{a}$ and $1 \mathrm{~b}$, IC50 values $>100 \mu \mathrm{M}$ ) induced significant changes on DNA mobility. It is assumed that in the conditions of the gel mobility assay $(40 \mu \mathrm{M} / \mathrm{mL}, 0.8 \mu \mathrm{g}$ DNA) noncytotoxic cyclopalladated compounds such as $1 \mathrm{a}$ and $1 \mathrm{~b}$ interacted to some extent with DNA in a similar way to that of cisplatin. On the other hand, compounds bearing the triphenylphosphane ligand, such as 1e (IC50 >100 $\mu \mathrm{M}$, in the three lines assessed) and 3e (IC50 $=5.5 \mu \mathrm{M}$ in MDA-MB231), did not modify plasmid DNA migration, pointing out another mechanism of action or another biomolecular target from that of cisplatin.

Although intercalation has been traditionally associated with molecules containing fused bi- or tricyclic ring structures, atypical intercalators might be more prevalent than originally thought.19 In order to ascertain whether compound 3e, which has a similar potency to that of cisplatin against MDA-MB231 breast cancer cells, could be a DNA intercalator, a topoisomerase-based gel assay was performed.20

Supercoiled pBluescript plasmid DNA was incubated in the presence of topoisomerase I and increasing concentrations of compound 3e. Results presented in Figure 8 showed that $3 \mathrm{e}$ does not prevent unwinding of DNA by the action of topoisomerase I, indicating that this compound is neither an intercalator nor an inhibitor of topoisomerase I.21

In conclusion, all the palladated compounds containing the fragment $\mathrm{NCH} 2 \mathrm{CH} 2 \mathrm{OCH} 2 \mathrm{CH} 2 \mathrm{OCH} 2 \mathrm{CH} 2 \mathrm{~N}$ exhibited a remarkable cytotoxic effectiveness. Interestingly, complex $3 \mathrm{a}$ was found to inhibit cell growth proliferation of the MCF7 breast cell line at a level ca. 4 times higher than that of cisplatin. In contrast, all the complexes containing the $\mathrm{NCH} 2 \mathrm{CH} 2 \mathrm{~N}$ fragment showed no cytotoxic activity. The remarkable difference in the activity of these two series of similar compounds shows the importance of the flexibility, hydrophilicity, and lipophilicity to the cytotoxic activity of coordination complexes.

All the cyclopalladated complexes, with the exception of 1e and 3e, featuring a triphenylphosphane ligand, modify the helicity of plasmid DNA, although to a lesser extent than cisplatin, pointing to another mechanism of action or a biomolecular target different from cisplatin.

Further studies are in progress centered on both the mechanistic elucidation (cell cycle arrest, induction of apoptosis, etc.) of the cytotoxic activity of these polynuclear palladium(II) complexes and the development of more potent polymetalated derivatives. 
Materials and Methods. All the operations were carried out in air, unless otherwise stated. All chemicals were obtained from commercial sources and used as received. Solvents were distilled and dried before use. 22 The synthesis and chracterization data of the biologically nonactive compounds $1 \mathrm{a}-\mathrm{e}$ and $2 \mathrm{a}-\mathrm{e}$ are given in the Supporting Information.

MALDI TOF (+) spectra were registered using dithranol (DTH), 2,5-dihydroxybenzoic acid (DHB), or trans-2-[3-(4-tert-butylphenyl)-2-methyl-2-propenylidene]malononitrile (DCTB) as a matrix. Chemical ionization $(\mathrm{CI})(+)$ mass spectra were recorded using ammonia as the reagent gas. Low-resolution ESI $(+)$ spectra were acquired utilizing a mixture of $\mathrm{H} 2 \mathrm{O} / \mathrm{CH} 3 \mathrm{CN}(1: 1, \mathrm{v} / \mathrm{v})$ as the eluent. As for the MS notation, M1 refers to one dimetalated moiety linked by two $\mathrm{X}$ bridging ligands, M2 designates two dimetalated moieties bound by four $\mathrm{X}$ bridging ligands, and NN represents 2,2'-(ethylenedioxy)bis(ethylamine).

Infrared spectra were obtained using $\mathrm{KBr}$ pellets. The solvent used in the $1 \mathrm{H}$ and $13 \mathrm{C}\{1 \mathrm{H}\} \mathrm{NMR}$ experiments was $\mathrm{CDCl} 3(99.9 \%)$, and the references were SiMe4 $[\delta(1 \mathrm{H})=0.00 \mathrm{ppm})]$ or the solvent peak $[\delta(13 \mathrm{C})=77.00]$, respectively. The $31 \mathrm{P}\{1 \mathrm{H}\} \mathrm{NMR}$ spectra were registred in $\mathrm{CDCl} 3, \mathrm{CHCl} 3$, or acetone-d6 and were referenced to $\mathrm{P}(\mathrm{OMe}) 3[\delta(31 \mathrm{P})=140.17 \mathrm{ppm}]$. The chemical shifts $(\delta)$ are given in ppm, and the coupling constants (J) in Hz. In the characterization section of each product the assignment of signals detected in the NMR spectra refers to the labeling patterns presented in Scheme 1 and Chart 2.

X-ray Diffraction. In all cases, a prismatic crystal was selected and mounted on a diffractometer fitted with an image plate detector. Intensities were collected with graphite-monochromatized Mo K $\alpha$ radiation. Structures were solved by Patterson synthesis [adduct $1 \mathrm{~d} \cdot 3(\mathrm{CDCl} 3)$ ] or direct methods $[1 \mathrm{e} \cdot 4(\mathrm{CDCl} 3)$ and $2 \mathrm{~d} \cdot 2(\mathrm{CDCl} 3)]$ using the SHELXS computer program 23 and refined by full-matrix leastsquares method with the SHELX97 computer program.24 The crystals of sample 1e, susceptible to solvent loss, were coated in perfluoroalkyl ether, and X-ray determinations were measured at $203 \mathrm{~K}$. As samples $1 \mathrm{~d} \cdot 3(\mathrm{CDCl} 3)$ and $2 \mathrm{~d} \cdot 2(\mathrm{CDCl} 3)$ were air stable, $\mathrm{X}$-ray analyses were performed at ambient temperature.

CCDC nos. 995314 (2d), 995315 (1e), and 995316 (1d) contain the supplementary crystallographic data for this paper. These data are also available free of charge via www.ccdc.cam.ac.uk/cgi-bin/catreqcgi or from the Cambridge Crystallographic Data Centre, 12 Union Road, Cambridge CB2 1EZ, UK (fax: +44 1223-336-033; e-mail: deposit@ ccdc.cam.ac.uk).

Synthesis of Compounds a. 3a: A Schlenk tube loaded with ligand $3(503 \mathrm{mg}, 1.28 \mathrm{mmol})$ and palladium(II) acetate $(583 \mathrm{mg}, 2.60 \mathrm{mmol}$ ) was evacuated and flushed with nitrogen three times. Freshly distilled toluene $(25 \mathrm{~mL})$ was added to the flask. The crude reaction mixture was maintained at $60{ }^{\circ} \mathrm{C}$ for $5 \mathrm{~h}$ under stirring, after which time the metallic deposit formed was removed by filtration. Filtrate was concentrated under reduced pressure and next subjected to flash column chromatography over silica gel $(\Phi=3 \mathrm{~cm} \times 23.5 \mathrm{~cm})$ eluting with 100:2 chloroform/methanol, gradually increasing the polarity to 100:4 and 100:6. The second eluted band was collected to give $3 \mathrm{a}$ after solvent removal. A deep-orange solid precipitated via addition of diethyl ether $(5 \mathrm{~mL})$, which was subsequently filtered and air-dried (507 mg, 55\% yield). IR (cm-1): 1613 (C円N st), 1561 (COO as st), 1417 (COO sym st). MS-MALDI TOF (+) (DHB), m/z: 660.7 (calcd 660.9) [M1 - AcO]+. Anal. Calcd for (C24H26Cl2N2O6Pd2)n [Mr $(722.22 \times \mathrm{n})]$ : C 39.91, H 3.63, N 3.88. Found: C 39.5, H 3.5, N 3.7.

4a: Aldimine 4 (511 mg, $1.33 \mathrm{mmol})$ and palladium(II) acetate $(597 \mathrm{mg}, 2.66 \mathrm{mmol})$ were brought into a Schlenk flask, evacuated for $10 \mathrm{~min}$, and finally flushed with nitrogen. To this was added glacial acetic acid $(40 \mathrm{~mL})$. The reaction mixture was heated to $60^{\circ} \mathrm{C}$ and maintained at this temperature for $6 \mathrm{~h}$. After this time, the resulting mixture was then concentrated to dryness and subjected to column 
chromatography over silica gel $(\Phi=3 \mathrm{~cm} \times 24 \mathrm{~cm})$ using a chloroform/methanol solvent system. Eluent polarity was gradually increased from 100:2, to 100:3, to 100:5. 4a was obtained as a deep yellow powder after solvent removal and addition of diethyl ether $(5 \mathrm{~mL})$. The product was collected by filtration and air-dried (377 mg, 40\% yield). IR ( $\mathrm{cm}-1)$ : 1609 (C=N st), 1569 (COO as st), 1413 (COO sym st), 1264 (CH3-O-Car as st), 1035 (CH3-O-Car sym st). MS-MALDI TOF (+) (DHB), m/z: 488.2 (calcd 488.2) [M1 - $2 \mathrm{AcO}-\mathrm{Pd}]+$. Anal. Calcd for $(\mathrm{C} 26 \mathrm{H} 32 \mathrm{~N} 2 \mathrm{O} 8 \mathrm{Pd} 2) \mathrm{n}[\mathrm{Mr}(713.38 \times \mathrm{n})]: \mathrm{C} 43.77, \mathrm{H}$ 4.52, N 3.93. Found: C 43.2, H 4.4, N 3.7.

5a: To a Schlenk tube were charged ligand $5(470 \mathrm{mg}, 1.13 \mathrm{mmol})$ and palladium(II) acetate $(500 \mathrm{mg}$, $2.23 \mathrm{mmol})$. An evacuation/backfill cycle was applied three times. Glacial acetic acid $(25 \mathrm{~mL})$ was then added to the flask. The crude reaction mixture was held at $60{ }^{\circ} \mathrm{C}$ for $5 \mathrm{~h}$ under stirring, after which time the solvent was removed in vacuo. The residue was redissolved in a 100:5 chloroform/methanol mixture and soon afterward passed through a short silica plug $(\Phi=3 \mathrm{~cm} \times 4.5 \mathrm{~cm})$. The silica was washed with the same solvent system until the washings went colorless. The resulting reddish filtrate was immediately reduced under vacuum since complex 5a slowly darkens in a 100:5 chloroform/methanol solution. Filtration must be performed at once to prevent decomposition to palladium black. Addition of diethyl ether $(5 \mathrm{~mL})$ yielded a maroon-colored solid, which was subsequently filtered and air-dried (260 $\mathrm{mg}, 31 \%$ yield). IR (cm-1): 1618 (C=N st), 1563 (COO as st), 1516 (NO2 as st), 1415 (COO sym st), 1339 (NO2 sym st). MS-MALDI TOF (+) (DTH), m/z: 683.0 (calcd 683.2) [M1 - AcO]+. Anal. Calcd for $(\mathrm{C} 24 \mathrm{H} 26 \mathrm{~N} 4 \mathrm{O} 10 \mathrm{Pd} 2) n$ [Mr $(743.32 \times \mathrm{n})]$ : C 38.78, H 3.53, N 7.54. Found: C 38.6, H 3.7, N 7.5.

6a: Aldimine 6 (256 mg, $0.65 \mathrm{mmol})$ and palladium(II) acetate (290 mg, $1.29 \mathrm{mmol})$ were combined in glacial acetic acid $(40 \mathrm{~mL})$, and the resulting mixture was allowed to stir at room temperature for a couple of days. After this period, an orange solid corresponding to the acetato-bridged complex 6a was observed. The mixture was then concentrated to dryness and subjected to column chromatography over silica gel $(\Phi=2.5 \mathrm{~cm} \times 19 \mathrm{~cm})$ using a 100:2 chloroform/ methanol solvent system. Eluent polarity was gradually increased to 100:3, 100:4, and 100:5. The colored band led to the desired precipitate after solvent removal followed by addition of diethyl ether (ca. $10 \mathrm{~mL}$ ). The product was finally separated by filtration and airdried (149 mg, 32\% yield). IR (cm-1): 1605 (CФN st), 1562 (COO as st), 1411 (COO sym st). MS-MALDI TOF (+) (DTH), m/z: 661.1 (calcd 660.9) [M1 - AcO]+. Anal. Calcd for $(\mathrm{C} 24 \mathrm{H} 26 \mathrm{Cl} 2 \mathrm{~N} 2 \mathrm{O} 6 \mathrm{Pd} 2) \mathrm{n}[\mathrm{Mr}(722.22 \times$ n)]: C 39.91, H 3.63, N 3.88. Found: C 39.5, H 3.5, N 3.8.

Synthesis of Compounds b. $3 \mathrm{~b}$ : To a suspension of acetatobridged complex $3 \mathrm{a}(174 \mathrm{mg}, 0.12 \mathrm{mmol})$ in acetone $(30 \mathrm{~mL})$ was added an excess of lithium chloride $(47 \mathrm{mg}, 1.12 \mathrm{mmol})$. The resulting

mixture was stirred at room temperature for 1 day. As the solution turned yellow, an off-white precipitate ascribed to lithium salts formed. The reaction crude was filtered and reduced in vacuo. Upon subjecting the mixture to flash column chromatography $(\mathrm{SiO} 2, \Phi=3.5 \mathrm{~cm} \times 2 \mathrm{~cm})$, using acetone as an eluent, a colored band developed in the column. This fraction was collected and the solvent removed under reduced pressure. Addition of a small volume of diethyl ether (ca. $5 \mathrm{~mL}$ ) rendered pure $3 \mathrm{~b}$ as a cream-colored solid (121 mg, 74\% yield). IR (cm-1): 1612 (C=N st). MS-MALDI TOF (+) (DTH), m/z: $637.0($ calcd 636.9) $[\mathrm{M} 1-\mathrm{Cl}]+$.

$4 \mathrm{~b}$ : Complex $4 \mathrm{~b}$ was synthesized by adding lithium chloride $(47 \mathrm{mg}, 1.11 \mathrm{mmol})$ to a suspension of acetato-bridged complex $4 \mathrm{a}(130 \mathrm{mg}, 0.09 \mathrm{mmol})$ in acetone $(30 \mathrm{~mL})$. The resultant mixture was intensely stirred at ambient temperature for 1 day. The reaction crude was then concentrated under reduced pressure. Addition of diethyl ether led to a pale yellow precipitate, which was filtered off and repeatedly washed with deionized water $(6 \times 5 \mathrm{~mL})$ and a small portion of chilled acetone $(0.5 \mathrm{~mL})(92$ $\mathrm{mg}, 76 \%$ yield). IR (cm-1): 1608 (C=N st), 1267 (CH3-O-Car as st), 1032 (CH3-O-Car sym st). MSMALDI TOF (+) (DHB), m/z: $629.2($ calcd 629.0) [M1 - Cl]+. 
mixture was allowed to stir for $2 \mathrm{~h}$, and then volatiles were reduced under vacuum. Upon addition of diethyl ether, an intense yellow solid precipitated, which was recovered by filtration, washed repeatedly with water $(6 \times 4 \mathrm{~mL})$ and a small portion of chilled ethanol $(2 \mathrm{~mL})$, and finally dried in air $(27 \mathrm{mg}$, 85\% yield). IR (cm-1): $1616(\mathrm{C}=\mathrm{N}$ st), 1516 (NO2 as st), 1339 (NO2 sym st). MS-MALDI TOF (+) (DTH), m/z: $659.0($ calcd 658.9) [M1 - Cl]+.

6b: Acetato-bridged complex 6a (100 mg, $0.07 \mathrm{mmol})$ was dissolved in chloroform $(50 \mathrm{~mL})$ after $1 \mathrm{~h}$ of vigorous stirring. A solution of lithium chloride $(23 \mathrm{mg}, 0.55 \mathrm{mmol})$ in acetone $(10 \mathrm{~mL})$ was stirred for $5 \mathrm{~min}$ and next poured into the chloroform solution. The resultant yellow mixture was allowed to stand at ambient temperature for approximately $45 \mathrm{~min}$, during which time the solution lightened to an extremely pale yellow. Also lithium acetate precipitated out, which was eliminated by filtration and discarded. The filtrate was evaporated under vacuum, to yield the expected product upon addition of diethyl ether (ca. $5 \mathrm{~mL}$ ). The yellow solid obtained was filtered off and air-dried ( $86 \mathrm{mg}, 92 \%$ yield). IR (cm-1): $1609(\mathrm{C} \bigoplus \mathrm{N}$ st). MSMALDI TOF (+) (DHB), m/z: $636.9($ calcd 636.9) [M1 - Cl]+.

Synthesis in Solution of Compounds $\mathbf{c}$ and d. A solution constituted by the acetato-bridged or chlorido cyclopalladated compound (ca. $10 \mathrm{mg}$ ) in deuterated chloroform (approximately $0.7 \mathrm{~mL}$ ) was treated with deuterated pyridine (ca. 2 drops) and shaken for a few seconds. The resultant solution became lighter, which indicated the quantitative formation of the corresponding dinuclear derivative. Due to the rapid exchange between the coordinated and the free pyridine-d5, carbon NMR signals of the coordinated pyridine-d5 were not observed for compounds $2 \mathrm{c}, 3 \mathrm{~d}, 5 \mathrm{c}, 5 \mathrm{~d}, 6 \mathrm{c}$, and $6 \mathrm{~d}$.

Characterization Data. 3c: 1H NMR (400 MHz, CDCl3, $298 \mathrm{~K}): 7.87(\mathrm{~s}, 1 \mathrm{H}, \mathrm{CH} 7=\mathrm{N}), 7.21(\mathrm{~d}, \mathrm{JHH}=$ $8.0 \mathrm{~Hz}, 1 \mathrm{H}, \mathrm{H} 5), 7.00$ (dd, JHH = 8.0 Hz, JHH = 1.9 Hz, $1 \mathrm{H}, \mathrm{H} 4), 6.12(\mathrm{~d}, \mathrm{JHH}=1.9 \mathrm{~Hz}, 1 \mathrm{H}, \mathrm{H} 2$ ), 3.81 (apparent t, J $\approx 4-5 \mathrm{~Hz}, 2 \mathrm{H}, \mathrm{CH} 2$ 9-O), 3.65 (s, $2 \mathrm{H}, \mathrm{CH} 2$ 10-O), 3.65-3.64 (m, $2 \mathrm{H}, \mathrm{CH} 2$ 8-N), 1.87 (s, $3 \mathrm{H}, \mathrm{CH} 3-\mathrm{COO}) .13 \mathrm{C}\{1 \mathrm{H}\} \mathrm{NMR}(101 \mathrm{MHz}, \mathrm{CDCl} 3,298 \mathrm{~K}): 178.0$ (s, CH3-COO), 176.0 (s, $\mathrm{CH7}=\mathrm{N}$ ), 158.1 (s, C1), 152.8 (apparent t, J $\approx 26-29 \mathrm{~Hz}, \mathrm{o}-\mathrm{Cpy}-\mathrm{d} 5), 145.5$ (s, C6), 138.3-137.7 (m, pCpy-d5), 136.0 (s, C3), 132.6 (s, C2), 128.4 (s, C5), 125.2 (apparent t, J = 23 Hz, m-Cpy-d5), 124.6 (s, C4), 70.6 (s, CH2 10-O), 68.6 (s, CH2 9-O), 58.8 (s, CH2 8-N), 24.8 (s, CH3-COO).

3d: 1H NMR (400 MHz, CDCl3, 298 K): 7.93 (s, 1 H, CH7=N), 7.28 (d, JHH = 8.0 Hz, 1 H, H5), 7.04 $(\mathrm{dd}, \mathrm{JHH}=8.0 \mathrm{~Hz}, \mathrm{JHH}=1.9 \mathrm{~Hz}, 1 \mathrm{H}, \mathrm{H} 4), 6.08$ (d, JHH = 1.4 Hz, $1 \mathrm{H}, \mathrm{H} 2), 3.92$ (s, $4 \mathrm{H}, \mathrm{CH} 2$ 9-O + CH2 8-N), 3.64 (s, 2 H, CH2 10-O). 13C $\{1 \mathrm{H}\}$ NMR (101 MHz, CDCl3, $298 \mathrm{~K})$ : $176.5(\mathrm{~s}, \mathrm{CH} 7=\mathrm{N})$, 159.3 (s, C1), 145.1 (s, C6), 136.2 (s, C3), 131.7 (s, C2), 128.4 (s, C5), 124.7 (s, C4), 70.6 (s, CH2 10-O), 69.1 (s, CH2 9-O), 59.7 (s, CH2 8-N).

4c: 1H NMR (400 MHz, CDCl3, $298 \mathrm{~K}$ ): 7.79 (s, $1 \mathrm{H}, \mathrm{CH} 7=\mathrm{N}), 7.23$ (d, JHH = 8.2 Hz, $1 \mathrm{H}, \mathrm{H} 5), 6.49$ (d, JHH = 8.0 Hz, 1 H, H4), 5.70 (s, 1 H, H2), 3.79 (br s, 2 H, CH2 9-O), 3.66 (s, 2 H, CH2 10-O), 3.62 (s, $3 \mathrm{H}, \mathrm{CH} 311-\mathrm{O}), 3.60$ (br s, $2 \mathrm{H}, \mathrm{CH} 28-\mathrm{N}), 1.87$ (s, $3 \mathrm{H}, \mathrm{CH} 3-\mathrm{COO}) .13 \mathrm{C}\{1 \mathrm{H}\} \mathrm{NMR}(101 \mathrm{MHz}$, $\mathrm{CDCl} 3,298 \mathrm{~K})$ : $177.6(\mathrm{~s}, \mathrm{CH} 3-\mathrm{COO}), 175.3(\mathrm{~s}, \mathrm{CH} 7=\mathrm{N}), 160.0$ (s, C3), 158.4 (s, C1), 153.1-152.5 (m, o-Cpy-d5), 140.2 (s, C6), 137.8-137.2 (m, p-Cpy-d5), 128.9 (s, C5), 124.9-124.4 (m, m-Cpy-d5), 119.7 (s, C2), 107.9 (s, C4), 70.4 (s, CH2 10-O), 68.7 (s, CH2 9-O), 58.3 (s, CH2 8-N), 54.9 (s, CH3 11-O), 24.6 (s, $\mathrm{CH} 3-\mathrm{COO})$.

4d: 1H NMR (400 MHz, CDCl3, 298 K): 7.85 (s, 1 H, CH7=N), 7.32 (d, JHH = 8.2 Hz, 1 H, H5), 6.54 $(\mathrm{dd}, \mathrm{JHH}=8.3 \mathrm{~Hz}, \mathrm{JHH}=2.1 \mathrm{~Hz}, 1 \mathrm{H}, \mathrm{H} 4), 5.66(\mathrm{~d}, \mathrm{JHH}=1.9 \mathrm{~Hz}, 1 \mathrm{H}, \mathrm{H} 2), 3.88-3.87$ (m, $4 \mathrm{H}, \mathrm{CH} 2$ $8-\mathrm{N}+\mathrm{CH} 2$ 9-O), 3.64 (s, $2 \mathrm{H}, \mathrm{CH} 210-\mathrm{O}), 3.63$ (s, $3 \mathrm{H}, \mathrm{CH} 311-\mathrm{O}) .13 \mathrm{C}\{1 \mathrm{H}\} \mathrm{NMR}(101 \mathrm{MHz}$, CDCl3, $298 \mathrm{~K}$ ): 176.1 (s, CH7=N), 160.3 (s, C3), 159.8 (s, C1), 153.0-152.4 (m, o-Cpy-d5), 139.9 (s, C6), 137.8-137.2 (m, p-Cpy-d5), 129.1 (s, C5), 125.1-124.6 (m, m-Cpy-d5), 119.0 (s, C2), 108.2 (s, C4), 70.6 (s, CH2 10-O), 69.4 (s, CH2 9-O), 59.3 (s, CH2 8-N), 55.0 (s, CH3 11-O).

5c: 1H NMR (400 MHz, CDCl3, $298 \mathrm{~K}): 8.06$ (s, $1 \mathrm{H}, \mathrm{CH} 7=\mathrm{N}), 7.91(\mathrm{dd}, \mathrm{JHH}=8.2 \mathrm{~Hz}, \mathrm{JHH}=2.2 \mathrm{~Hz}$, $1 \mathrm{H}, \mathrm{H} 4), 7.50(\mathrm{~d}, \mathrm{JHH}=8.2 \mathrm{~Hz}, 1 \mathrm{H}, \mathrm{H} 5), 6.89(\mathrm{~d}, \mathrm{JHH}=2.1 \mathrm{~Hz}, 1 \mathrm{H}, \mathrm{H} 2), 3.87-3.85$ (m, $2 \mathrm{H}, \mathrm{CH} 2$ 
9-O), 3.78-3.76 (m, $2 \mathrm{H}, \mathrm{CH} 28-\mathrm{N}), 3.67$ (s, $2 \mathrm{H}, \mathrm{CH} 210-\mathrm{O}), 1.94$ (s, $3 \mathrm{H}, \mathrm{CH} 3-\mathrm{COO}) .13 \mathrm{C}\{1 \mathrm{H}\}$ NMR (101 MHz, CDCl3, 298 K): 175.4 (s, CH7=N), 157.5 (s, C1), 152.3 (s, C6), 147.1 (s, C3), 127.5 (s, C5), 126.2 (s, C2), 119.9 (s, C4), 70.3 (s, CH2 10-O), 68.2 (s, CH2 9-O), 58.5 (s, CH2 8-N), 23.7 (br s, $\mathrm{CH} 3-\mathrm{COO}$ ).

5d: 1H NMR (400 MHz, CDCl3, $298 \mathrm{~K}): 8.11$ (s, $1 \mathrm{H}, \mathrm{CH} 7=\mathrm{N}), 7.91(\mathrm{dd}, \mathrm{JHH}=8.2 \mathrm{~Hz}, \mathrm{JHH}=2.2 \mathrm{~Hz}$, $1 \mathrm{H}, \mathrm{H} 4), 7.54$ (d, JHH = 8.2 Hz, $1 \mathrm{H}, \mathrm{H} 5), 6.94$ (d, JHH = 1.8 Hz, $1 \mathrm{H}, \mathrm{H} 2), 4.03$ (br s, $2 \mathrm{H}, \mathrm{CH} 2$ 8-N), 3.96 (br s, 2 H, CH2 9-O), 3.66 (s, 2 H, CH2 10-O). 13C \{1H\} NMR (101 MHz, CDCl3, 298 K): 176.1 (s, CH7=N), 158.9 (s, C1), 152.1 (s, C6), 147.4 (s, C3), 127.6 (s, C5), 125.7 (s, C2), 120.0 (s, C4), 70.8 (s, CH2 10-O), 69.1 (s, CH2 9-O), 60.3 (s, CH2 8-N).

6c: 1H NMR (400 MHz, CDCl3, $298 \mathrm{~K}$ ): 8.28 (s, $1 \mathrm{H}, \mathrm{CH} 7=\mathrm{N}), 6.94$ (dd, JHH = 8.0 Hz, JHH =0.8 Hz, $1 \mathrm{H}, \mathrm{H} 4), 6.82$ (t, JHH = 7.8 Hz, $1 \mathrm{H}, \mathrm{H} 3), 6.05$ (dd, JHH = 7.6 Hz, JHH = 0.7 Hz, $1 \mathrm{H}, \mathrm{H} 2$ ), 3.83 (br s, 2 H, CH2 9-O), 3.69 (s, 2 H, CH2 10-O), 3.68 (br s, 2 H, CH2 8-N), 1.87 (s, 3 H, CH3-COO). 13C $\{1 \mathrm{H}\}$ NMR (101 MHz, CDCl3, $298 \mathrm{~K}): 177.8$ (s, CH3-COO), $174.6(\mathrm{~s}, \mathrm{CH} 7=\mathrm{N}), 158.2(\mathrm{~s}, \mathrm{C} 1)$, 144.0 (s, C6), 131.6 (s, C5), 131.5 (s, C3), 131.0 (s, C2), 124.8 (s, C4), 70.4 (s, CH2 10-O), 68.3 (s, $\mathrm{CH} 2$ 9-O), 59.0 (s, CH2 8-N), 24.6 (s, CH3-COO).

6d: 1H NMR (400 MHz, CDCl3, 298 K): 8.29 (s, 1 H, CH7=N), 6.98 (d, JHH = 7.9 Hz, 1 H, H4), 6.85 $(\mathrm{t}, \mathrm{JHH}=7.8 \mathrm{~Hz}, 1 \mathrm{H}, \mathrm{H} 3), 6.00(\mathrm{~d}, \mathrm{JHH}=7.2 \mathrm{~Hz}, 1 \mathrm{H}, \mathrm{H} 2), 3.93(\mathrm{~s}, 4 \mathrm{H}, \mathrm{CH} 2 \mathrm{9}-\mathrm{O}+\mathrm{CH} 28-\mathrm{N}), 3.68$ (s, $2 \mathrm{H}, \mathrm{CH} 210-\mathrm{O}) .13 \mathrm{C}\{1 \mathrm{H}\}$ NMR (101 MHz, CDCl3, $298 \mathrm{~K}): 175.5$ (s, CH7=N), 159.5 (s, C1), 143.9 (s, C6), 131.9 (s, C5), 131.8 (s, C3), 130.3 (s, C2), 125.2 (s, C4), 70.3 (s, CH2 10-O), 68.9 (s, CH2 9-O), $60.0(\mathrm{~s}, \mathrm{CH} 28-\mathrm{N})$.

Synthesis of Compounds e. 3e: A stirred suspension of chloridobridged compound 3b (124 mg, 0.09 $\mathrm{mmol}$ ) in chloroform (ca. $30 \mathrm{~mL}$ ) was treated with small portions of triphenylphosphane (total addition: $98 \mathrm{mg}, 0.37 \mathrm{mmol}$ ). After $3 \mathrm{~h}$ of stirring at room temperature, the resultant solution was filtered and evaporated under vacuum. Crude was purified by column chromatography over silica gel in order to remove the free phosphane excess $(\Phi=2.5 \mathrm{~cm} \times 18 \mathrm{~cm})$. Elution was performed using a solvent system with a gradient of increasing polarity from chloroform to 100:2 chloroform/methanol. The yellow band was evaporated in vacuo. Addition of diethyl ether (ca. $5 \mathrm{~mL}$ ) resulted in the formation of a pale yellow solid, which was next filtered off and air-dried (73 mg, 33\% yield). 1H NMR (400 MHz, CDCl3, 298 $\mathrm{K}): 8.08(\mathrm{~d}, \mathrm{JHP}=8.0 \mathrm{~Hz}, 1 \mathrm{H}, \mathrm{CH} 7=\mathrm{N}), 7.74-7.69(\mathrm{~m}, 6 \mathrm{H}, \mathrm{o}-\mathrm{C} 6 \mathrm{H} 5), 7.47-7.42(\mathrm{~m}, 3 \mathrm{H}, \mathrm{p}-\mathrm{C} 6 \mathrm{H} 5)$, $7.38(\mathrm{td}, \mathrm{JHH}=7.2 \mathrm{~Hz}, \mathrm{JHP}=2.2 \mathrm{~Hz}, 6 \mathrm{H}, \mathrm{m}-\mathrm{C} 6 \mathrm{H} 5), 7.17(\mathrm{~d}, \mathrm{JHH}=8.0 \mathrm{~Hz}, 1 \mathrm{H}, \mathrm{H} 5), 6.83$ (dd, JHH = $8.0 \mathrm{~Hz}, \mathrm{JHH}=1.9 \mathrm{~Hz}, 1 \mathrm{H}, \mathrm{H} 4), 6.23(\mathrm{dd}, \mathrm{JHP}=5.8 \mathrm{~Hz}, \mathrm{JHH}=1.9 \mathrm{~Hz}, 1 \mathrm{H}, \mathrm{H} 2), 4.03(\mathrm{dd}, \mathrm{JHH}=8.9$ $\mathrm{Hz}, \mathrm{JHH}=4.4 \mathrm{~Hz}, 2 \mathrm{H}, \mathrm{CH} 28-\mathrm{N}), 3.86-3.84(\mathrm{~m}, 2 \mathrm{H}, \mathrm{CH} 2$ 9-O), 3.63 (s, $2 \mathrm{H}, \mathrm{CH} 210-\mathrm{O}) .13 \mathrm{C}\{1 \mathrm{H}\}$ NMR (101 MHz, CDCl3, 298 K): $176.3(\mathrm{~d}, \mathrm{JCP}=4.1 \mathrm{~Hz}, \mathrm{CH} 7=\mathrm{N}), 159.5$ (s, C1), 146.5 (s, C6), 137.4 $(\mathrm{d}, \mathrm{JCP}=10.6 \mathrm{~Hz}, \mathrm{C} 2), 135.7(\mathrm{~d}, \mathrm{JCP}=7.0 \mathrm{~Hz}, \mathrm{C} 3), 135.3(\mathrm{~d}, \mathrm{JCP}=11.7 \mathrm{~Hz}, \mathrm{o}-\mathrm{C} 6 \mathrm{H} 5), 130.9(\mathrm{~d}, \mathrm{JCP}=$ $2.5 \mathrm{~Hz}, \mathrm{p}-\mathrm{C} 6 \mathrm{H} 5), 130.4$ (d, JCP = 50.9 Hz, i-C6H5), 128.7 (s, C5), 128.2 (d, JCP = 11.0 Hz, m-C6H5), 124.1 (s, C4), 70.5 (s, CH2 10-O), 69.6 (s, CH2 9-O), 58.2 (s, CH2 8-N). 31P $\{1 \mathrm{H}\}$ NMR (101 MHz, CHCl3, 298 K): 40.0 (s). IR (cm-1): 1621 (C=N st), 1095 (q, X-sens.), 532 (y, Xsens.), 512 (y, X-sens.), 496 (y, X-sens.). MS-MALDI TOF (+) (DHB), m/z: 898.6 (calcd 899.0) [M - Cl - PPh3]+, 636.4 (calcd 636.9) [M - Cl-2 PPh3]+. Anal. Calcd for C56H50Cl4N2O2P2Pd2 (Mr 1199.61): C 56.07, H 4.20, N 2.34. Found: C 55.5, H 4.2, N 2.3.

4e: A flask loaded with chlorido-bridged complex $4 \mathrm{~b}(38 \mathrm{mg}, 0.03 \mathrm{mmol})$, triphenylphosphane $(29 \mathrm{mg}$, $0.11 \mathrm{mmol})$, and chloroform $(20 \mathrm{~mL}$ ) was maintained under constant stirring for $30 \mathrm{~min}$. During this time, the yellow solution became nearly colorless. Evaporation of the solvent followed by addition of diethyl ether (ca. $5 \mathrm{~mL}$ ) furnished the required product, which was then filtered off and air-dried $(60 \mathrm{mg}$, $88 \%$ yield). 1H NMR (400 MHz, CDCl3, $298 \mathrm{~K}): 8.03$ (d, JHP = 8.2 Hz, $1 \mathrm{H}, \mathrm{CH} 7=\mathrm{N}), 7.76-7.71$ (m, 6 H, o-C6H5), 7.45-7.40 (m, 3 H, p-C6H5), 7.38-7.34 (m, 6 H, m-C6H5), 7.19 (d, JHH = 8.3 Hz, $1 \mathrm{H}$, H5), $6.38(\mathrm{dd}, \mathrm{JHH}=8.3 \mathrm{~Hz}, \mathrm{JHH}=2.4 \mathrm{~Hz}, 1 \mathrm{H}, \mathrm{H} 4), 5.96(\mathrm{dd}, \mathrm{JHP}=6.4 \mathrm{~Hz}, \mathrm{JHH}=2.3 \mathrm{~Hz}, 1 \mathrm{H}, \mathrm{H} 2)$, 

11-O). 13C $\{1 \mathrm{H}\} \operatorname{NMR}(101 \mathrm{MHz}, \mathrm{CDCl} 3,298 \mathrm{~K}): 176.2(\mathrm{~d}, \mathrm{JCP}=3.8 \mathrm{~Hz}, \mathrm{CH} 7=\mathrm{N}), 160.7$ (s, C1), i-C6H5), 130.8 (d, JCP = 1.9 Hz, p-C6H5), 129.2 (s, C5), 128.1 (d, JCP = 10.8 Hz, m-C6H5), 123.1 (d, $\mathrm{JCP}=11.4 \mathrm{~Hz}, \mathrm{C} 2), 110.8(\mathrm{~s}, \mathrm{C} 4), 70.4(\mathrm{~s}, \mathrm{CH} 2$ 10-O), $69.9(\mathrm{~s}, \mathrm{CH} 2$ 9-O), 57.9 (s, CH2 8-N), 54.6 (s, CH3 11-O). 31P $\{1 \mathrm{H}\}$ NMR (101 MHz, acetone-d6, $298 \mathrm{~K}): 41.6$ (s). IR (cm-1): 1620 (C=N st), 1234/1217 (CH3-O-Car as st, split), 1096 (q, Xsens.), 1027 (CH3-O-Car sym st), 531 (y, X-sens.), 513 (y, X-sens.), 502 (y, X-sens.). MS-MALDI TOF (+) (DHB), m/z: 628.5 (calcd 629.0) [M - Cl-2 PPh3]+. Anal. Calcd for C58H56C12N2O4P2Pd2 (Mr 1190.77): C 58.50, H 4.74, N 2.35. Found: C 58.3, H 4.7, N 2.1.

5e: To a suspension of chlorido-bridged complex $5 \mathrm{~b}(49 \mathrm{mg}, 0.03 \mathrm{mmol})$ in acetone $(25 \mathrm{~mL})$ was added triphenylphosphane $(35 \mathrm{mg}, 0.13 \mathrm{mmol})$. The mixture was stirred for $1 \mathrm{~h}$ at room temperature. After evaporation of the solvent, the mixture was then subjected to column chromatography over silica gel ( $\Phi$ $=2.5 \mathrm{~cm} \times 29 \mathrm{~cm}$ ) using a 100:60 ethyl acetate/hexane solvent system. Eluent polarity was gradually increased to 100:30, and finally ethyl acetate was employed. The target product was obtained after solvent removal followed by addition of diethyl ether (ca. $5 \mathrm{~mL}$ ). The pale yellow precipitate was separated by filtration and air-dried (39 mg, 45\% yield). 1H NMR (400 MHz, CDCl3, $298 \mathrm{~K}): 8.25$ (d, $\mathrm{JHP}=7.9 \mathrm{~Hz}, 1 \mathrm{H}, \mathrm{CH7}=\mathrm{N}), 7.74-7.68(\mathrm{~m}, 7 \mathrm{H}, \mathrm{o}-\mathrm{C} 6 \mathrm{H} 5+\mathrm{H} 4), 7.47-7.36$ (m, $10 \mathrm{H}, \mathrm{p}-\mathrm{C} 6 \mathrm{H} 5+\mathrm{H} 5+$ m- C6H5), 7.24 (dd, 1 H, JHP = 5.8 Hz, JHH = 2.1 Hz, H2), 4.14-4.10 (m, 2 H, CH2 8-N), 3.91-3.89 (m, 2 H, CH2 9-O), 3.64 (s, 2 H, CH2 10-O). 13C\{1H\} NMR (101 MHz, CDC13, 298 K): 175.8 (d, $\mathrm{JCP}=4.2 \mathrm{~Hz}, \mathrm{CH7}=\mathrm{N}), 159.4(\mathrm{~s}, \mathrm{C1}), 153.7$ (s, C6), 146.8 (d, JCP = 5.8 Hz, C3), 135.2 (d, JCP = 11.7 Hz, o-C6H5), 131.4 (d, JCP = 11.6 Hz, C2), 131.2 (d, JCP = 2.3 Hz, p-C6H5), 129.8 (d, JCP = 52.0 Hz, i-C6H5), 128.4 (d, JCP = 11.1 Hz, m-C6H5), 127.9 (s, C5), 119.4 (s, C4), 70.7 (s, CH2 10-O), 69.5 (s, CH2 9-O), 58.7 (s, CH2 8-N). 31P $\{1 \mathrm{H}\}$ NMR (121 MHz, CDCl3, 298 K): 39.8 (s). IR (cm-1): 1628 (C†N st), 1517 (NO2 as st), 1339 (NO2 sym st), 1098 (q, X-sens.), 533 (y, X-sens.), 512 (y, Xsens.), 500 (y, X-sens.). MS-MALDI TOF (+) (DTH), m/z: $921.2($ calcd 921.0) [M - Cl - PPh3]+, 659.0 (calcd 658.9) [M - Cl-2 PPh3]+. Anal. Calcd for C56H50Cl2N4O6P2Pd2 (Mr 1220.71): C 55.10, H 4.13, N 4.59. Found: C 55.5, H 4.1, N 4.5.

6e: Chlorido-bridged complex $6 \mathrm{~b}(60 \mathrm{mg}, 0.04 \mathrm{mmol})$ and triphenylphosphane $(46 \mathrm{mg}, 0.17 \mathrm{mmol})$ were combined in chloroform $(20 \mathrm{~mL})$. After $30 \mathrm{~min}$ of stirring at room temperature, the solution obtained was concentrated to dryness using a rotatory evaporator. Addition of diethyl ether (ca. $5 \mathrm{~mL}$ ) furnished the desired product as a cream-colored powder, which was collected by filtration and dried in air $(85$ mg, 81\% yield). 1H NMR (400 MHz, CDCl3, $298 \mathrm{~K}): 8.61$ (d, JHP = 8.6 Hz, $1 \mathrm{H}, \mathrm{CH} 7=\mathrm{N}), 7.74-7.69$ (m, 6 H, o- C6H5), 7.45-7.42 (m, 3 H, p-C6H5), $7.36(\mathrm{td}, \mathrm{JHH}=8.0 \mathrm{~Hz}, \mathrm{JHP}=2.0 \mathrm{~Hz}, 6 \mathrm{H}, \mathrm{m}-\mathrm{C} 6 \mathrm{H} 5)$, $6.81(\mathrm{~d}, \mathrm{JHH}=8.0 \mathrm{~Hz}, 1 \mathrm{H}, \mathrm{H} 4), 6.43(\mathrm{t}, \mathrm{JHH}=7.8 \mathrm{~Hz}, 1 \mathrm{H}, \mathrm{H} 3), 6.26$ (apparent t, JHH $+\mathrm{JHP} \approx 6.8 \mathrm{~Hz}$, $1 \mathrm{H}, \mathrm{H} 2), 4.10-4.05(\mathrm{~m}, 2 \mathrm{H}, \mathrm{CH} 28-\mathrm{N}), 3.86$ (m, $2 \mathrm{H}, \mathrm{CH} 2$ 9-O), 3.69 (s, $2 \mathrm{H}, \mathrm{CH} 210-\mathrm{O}) .13 \mathrm{C}\{1 \mathrm{H}\}$ NMR (101 MHz, CDCl3, 298 K): 175.4 (d, JCP = 4.3 Hz, CH7=N), 160.0 (s, C1), 145.0 (s, C6), 136.6 $(\mathrm{d}, \mathrm{JCP}=10.6 \mathrm{~Hz}, \mathrm{C} 2), 135.4(\mathrm{~d}, \mathrm{JCP}=11.9 \mathrm{~Hz}, \mathrm{o}-\mathrm{C} 6 \mathrm{H} 5), 132.0$ (s, C5), $131.2(\mathrm{~d}, \mathrm{JCP}=5.7 \mathrm{~Hz}, \mathrm{C} 3)$, 130.9 (d, JCP = 2.4 Hz, p-C6H5), 130.8 (d, JCP = 50.8 Hz, i-C6H5), 128.1 (d, JCP = 11.0 Hz, mC6H5), 124.9 (s, C4), 70.3 (s, CH2 10-O), 69.5 (s, CH2 9-O), 58.5 (s, CH2 8-N). 31P\{1H\} NMR (101 MHz, CHCl3, 298 K): 41.2 (s). IR (cm-1): 1620 (C=N st), 1097 (q, X-sens.), 533 (y, X-sens.), 513 (y, X-sens.), 503 (y, X-sens.). MS-MALDI TOF (+) (DHB), m/z: 898.9 (calcd 899.0) [M - Cl - PPh3]+, 636.9 (calcd 636.9) [M - Cl-2 PPh3]+. Anal. Calcd for C56H50C14N2O2P2Pd2 (Mr 1199.61): C 56.07, H 4.20, N 2.34. Found: C 55.8, H 4.2, N 2.3.

Synthesis of Compound 3f. To a stirred suspension of chloridobridged complex $3 \mathrm{~b}$ (193 mg, 0.14 $\mathrm{mmol}$ ) in chloroform (ca. $25 \mathrm{~mL}$ ) was added 2,2'-(ethylenedioxy)bis(ethylamine) (42 mg, $0.28 \mathrm{mmol}$ ). The reaction mixture was allowed to stir for $4 \mathrm{~h}$ at room temperature, after which time the suspension obtained was reduced under vacuum. Addition of a mixture of diethyl ether/hexanes (ca. $7 \mathrm{~mL}$ ) yielded 
the product $3 \mathrm{f}$ as a yellow-colored solid, which was filtered off and airdried ( $212 \mathrm{mg}, 91 \%$ yield). $1 \mathrm{H}$ NMR (500 MHz, CDCl3, 298 K): 7.90 (s, 1 H, CH7=N), 7.30 (d, JHH = 8.0 Hz, 1 H, H5), 7.15 (dd, $\mathrm{JHH}=8.0 \mathrm{~Hz}, \mathrm{JHH}=1.9 \mathrm{~Hz}, 1 \mathrm{H}, \mathrm{H} 4), 7.03(\mathrm{~d}, \mathrm{JHH}=1.9 \mathrm{~Hz}, 1 \mathrm{H}, \mathrm{H} 2), 3.82(\mathrm{~s}, 2 \mathrm{H}, \mathrm{CH} 2 \mathrm{13}-\mathrm{O})$, 3.81-3.77 (m, 2 H, CH2 9-O), 3.71-3.67 (m, 4 H, CH2 8-N + CH212-O), 3.63 (s, 2 H, CH2 10-O), 3.15-3.11 (br m, $2 \mathrm{H}, \mathrm{CH} 21-\mathrm{NH} 2), 3.04-3.02$ (br m, $2 \mathrm{H}, \mathrm{NH} 2) .13 \mathrm{C}\{1 \mathrm{H}\}$ NMR (101 MHz, CDCl3, $298 \mathrm{~K}): 175.4$ (s, CH7=N), 157.9 (s, C1), 145.7 (s, C6), 135.8 (s, C3), 130.1 (s, C2), 128.9 (s, C5), 125.1 (s, C4), 71.4 (s, CH2 13-O), 71.2 (s, CH2 12-O), 70.3 (s, CH2 10-O), 68.9 (s, CH2 9-O), 59.0 (s, CH2 $8-\mathrm{N}), 45.8$ (s, CH2 11-NH2). IR (cm-1): 3225 (NH2 as st), 3143 (NH2 sym st), 1617 (C=N st). HRMS-ESI (+) $(\mathrm{H} 2 \mathrm{O} / \mathrm{CH} 3 \mathrm{CN}(1: 1)), \mathrm{m} / \mathrm{z}: 867.0445(\mathrm{calcd} 867.0402)[\mathrm{M}-\mathrm{Cl}+2 \mathrm{CH} 3 \mathrm{CN}]+, 826.0185$ (calcd 826.0137) $[\mathrm{M}-\mathrm{Cl}+\mathrm{CH} 3 \mathrm{CN}]+, 784.9872($ calcd 784.9872$)[\mathrm{M}-\mathrm{Cl}]+, 636.8655($ calcd 636.8660) $[\mathrm{M}-\mathrm{Cl}-(\mathrm{NN})]+$.

Biological Studies. Cell Culture. Breast cancer (MCF-7 and MBAMD-231) and colon cancer (HCT116) cells were grown as a monolayer culture in minimum essential medium (DMEM with Lglutamine, without glucose, and without sodium pyruvate) in the presence of $10 \%$ heat-inactivated fetal calf serum, $10 \mathrm{mM}$ D-glucose, and $0.1 \%$ streptomycin/penicillin, in standard culture conditions (humidified air with $5 \% \mathrm{CO} 2$ at $37^{\circ} \mathrm{C}$ ).

Cell Viability Assay. A stock solution $(50 \mathrm{mM})$ of each compound was prepared in high-purity DMSO. Then, serial dilutions were made with DMSO (1:1), and finally a 1:500 dilution of the diluted solutions of compounds on cell media was prepared. In this way DMSO concentration in cell media was always the same. The assay was performed as described by Givens et al.25 MDA-MB231 and MCF7 cells were plated at 5000 cells/well, respectively, in $100 \mathrm{~mL}$ of media in 96 -well tissue culture plates (Cultek). After $24 \mathrm{~h}$, media was replaced by $100 \mathrm{~mL} /$ well of drug serial dilutions. Control wells did not contain any complex. Each point concentration was run in triplicate. Reagent blanks, containing media and colorimetric reagent without cells, were run on each plate. Blank values were subtracted from test values and were routinely $5-10 \%$ of the control values. Plates were incubated $72 \mathrm{~h}$. Hexosaminidase activity was measured according to the following protocol. The media was removed, and cells were washed once with PBS. Then, $60 \mathrm{~mL}$ of substrate solution (p-nitrophenol-N-acetyl-b-Dglucosamide $7.5 \mathrm{mM}$, sodium citrate $0.1 \mathrm{M}$ at $\mathrm{pH} 5.0$, and $0.25 \%$ Triton X-100) was added to each well and incubated at $37{ }^{\circ} \mathrm{C}$ for $1-2$ $\mathrm{h}$. After this incubation time, a bright yellow solid appeared. Then, the plates were developed by adding $90 \mathrm{~mL}$ of developer solution (glycine $50 \mathrm{mM}, \mathrm{pH}$ 10.4; EDTA $5 \mathrm{mM}$ ), and the absorbance was recorded at $410 \mathrm{~nm}$.

DNA Migration Studies. A stock solution $(10 \mathrm{mM})$ of each compound was prepared in high-purity DMSO. Then, serial dilutions were made in Milli-Q water (1:1). Plasmid pBluescript SK + (Stratagene) was obtained using QIAGEN plasmid midi kit as described by the manufacturer. Interaction of drugs with pBluescript SK+ plasmid DNA was analyzed by agarose gel electrophoresis following a modification of the method described by Abdullah et al.26 Plasmid DNA aliquots ( $40 \mu \mathrm{g} \mathrm{mL}-1)$ were incubated in TE buffer (10 mM Tris-HCl, 1 mM EDTA, $\mathrm{pH}$ 7.5) with different concentrations of compounds $1 \mathrm{a}, 1 \mathrm{~b}, 1 \mathrm{e}, 3 \mathrm{a}, 3 \mathrm{~b}, 3 \mathrm{e}$, and $3 \mathrm{f}$ ranging from 0 to $200 \mu \mathrm{M}$ at $37^{\circ} \mathrm{C}$ for $24 \mathrm{~h}$. The final DMSO concentration in the reactions was always lower than $1 \%$. For comparison, cisplatin and ethidium bromide were used as reference controls. Aliquots of $20 \mu \mathrm{L}$ of the incubated solutions of compounds containing $0.8 \mu \mathrm{g}$ of DNA were subjected to $1 \%$ agarose gel electrophoresis in TAE buffer $(40 \mathrm{mM}$ Tris-acetate, $2 \mathrm{mM}$ EDTA, $\mathrm{pH}$ 8.0). The gel was stained in TAE buffer containing ethidium bromide $(0.5 \mathrm{mg} \mathrm{mL}-1)$ and visualized and photographed under UV light.

Topoisomerase I-based experiments were performed as described previously.20 Supercoiled pBluescript DNA, obtained as described above, was treated with topisomerase I in the absence or presence of increasing concentrations of compound 3e. Assay mixtures contained supercoiled pBluescript DNA ( 0.8 $\mu \mathrm{g})$, calf thymus topoisomerase I ( 3 units), and complex $3 \mathrm{e}(0-200 \mu \mathrm{M})$ in $20 \mu \mathrm{L}$ of Tris $-\mathrm{HCl}$ buffer $(\mathrm{Ph}$ 7.5) containing $175 \mathrm{mM} \mathrm{KCl}, 5 \mathrm{mM} \mathrm{MgCl}$, and $0.1 \mathrm{mM}$ EDTA. Ethidium bromide ( $10 \mu \mathrm{M})$ was used 
608 as a control of intercalating agents. Reactions were incubated for $30 \mathrm{~min}$ at $37^{\circ} \mathrm{C}$ and stopped by the 609 addition of $2 \mu \mathrm{L}$ of agarose gel loading buffer. Samples were then subjected to electrophoresis and DNA 610 bands stained with ethidium bromide as described above.

611 Computational Details. Molecular dynamics simulations were conducted using the MM3 force 612 field27,28 as implemented by the CAChe program (version 7.5.0.85).29 All DFT calculations were 613 carried out with the GAUSSIAN 03 package of programs30 using the B3LYP hybrid functional.31,32 614 The basis set was chosen as follows: LANL2DZ33,34 was used for palladium with an effective core 615 potential to replace the 36 innermost electrons of $\mathrm{Pd}$; for $\mathrm{H}, \mathrm{C}, \mathrm{N}, \mathrm{O}$, and $\mathrm{Cl}$ the 6-31G(d) basis set 616 including polarization functions for non-hydrogen atoms was used.35,36 Solvent effects were taken into 617 account using the CPCM model.37 PM6 calculations38 were performed using the Spartan '14 618 software.39 
620 AUTHOR INFORMATION

621

622 Corresponding Authors

623 *E-mail: joan.albert@qi.ub.es.

624 *E-mail: jaume.granell@,qi.ub.es.

625

626 Notes

627 The authors declare no competing financial interest.

628

629

630

631

632 


\section{ACKNOWLEDGMENTS}

634

635 Financial support from project CTQ2009-11501/BQU from the Spanish Ministerio de Ciencia e 636 Innovación and Grant 2009-SGR-1111 from Generalitat de Catalunya are acknowledged. 


\section{REFERENCES}

(1) (a) Dupont, J.; Consorti, C. S.; Spencer, J. Chem. Rev. 2005, 105, 2527. (b) Albrecht, M. Chem. Rev. 2010, 110, 576. (c) Palladacycles; Dupont, J.; Pfeffer, M., Eds.; Wiley-VCH: Weinheim, 2008

(2) (a) Kleiman, J. P.; Dubeck, M. J. Am. Chem. Soc. 1963, 85, 1544. (b) Cope, A. C.; Siekman, R. W. J. Am. Chem. Soc. 1965, 87, 327.

(3) For some interesting reactions and applications of cyclopalladated compounds see: (a) GarcíaLópez, J. A.; Oliva-Madrid, M. J.; Saura-Llamas, I.; Bautista, D.; Vicente, J. Chem. Commun. 2012, 6744. (b) Mancilha, F. S.; Barloy, L.; Rodembusch, F. S.; Dupont, J.; Pfeffer, M. Dalton Trans. 2011, 40, 10535. (c) Cautivo, T.; Klahn, H.; Godoy, F.; López, C.; Font-Bardia, M.; Calvet, T.; Gutiérrez-Puebla, E.; Monge, A. Organometallics 2011, 30, 5578. (d) Martin, R.; Crespo, M.; Font-Bardia, M.; Calvet, T. Organometallics 2009, 28, 587. (e) Bedford, R. B.; Betham, M.; Butts, C. P.; Coles, S. J.; Hursthouse, M. B.; Scully, P. N.; Tucker, J. H. R.; Wilkie, J.; Willener, Y. Chem. Commun. 2008, 2429. (f) Martínez, J.; Pereira, M. T.; Buceta, I.; Alberdi, G.; Amoedo, A.; Fernández, J. J.; López-Torres, M.; Vila, J. M. Organometallics 2003, 22, 5581. (g) López, B.; Rodríguez, A.; Santos, D.; Albert, J.; Ariza, X.; García, J.; Granell, J. Chem. Commun. 2011, 47, 1054. (h) Albert, J.; Crespo, M.; Granell, J.; Rodríguez, J.; Calvet, T.; Zafrilla, J.; Font-Bardia, M.; Solans, X. Organometallics 2010, 29, 214.

(4) For some pioneering studies in this field: (a) Quiroga, A. G.; Pérez, J. M.; López-Solera, I.; Masaguer, J. R.; Luque, A.; Román, P.; Edwards, A.; Alonso, C.; Navarro-Ranninger, C. J. Med. Chem. 1998, 41, 1399. (b) Zamora, F.; Gónzalez, V. M.; Pérez, J. M.; Masaguer, J. R.; Alonso, C.; Navarro-Ranninger, C. Appl. Organomet. Chem. 1997, 11, 659. (c) NavarroRanninger, C.; López-Solera, I.; González, V. M.; Pérez, J. M.; Álvarez-Valdés, A.; Martín, A.; Raithby, P. R.; Masaguer, J. R.; Alonso, C. Inorg. Chem. 1996, 35, 5181. (d) Higgins, J. D., III; Neely, L.; Fricker, S. J. Inorg. Biochem. 1993, 49, 149. (e) Yoneda, A.; Ouchi, M.; Hakushi, T.; Newkome, G. R.; Fronczek, F. R. Chem. Lett. 1993, 709. (f) Caires, A. C. F.; Almeida, E. T.; Mauro, A. E.; Hemerly, J. P.; Valentini, S. R. Quim. Nova 1999, 22, 329. 
(5) See for instance: (a) Aliwaini, S.; Swarts, A. J.; Blanckenberg, A.; Mapolie, S.; Prince, S. Biochem. Pharmacol. 2013, 86, 1650. (b) Albert, J.; Granell, J.; Llorca, A.; Lovelle, M. V.; Presa, A.; Moreno, V.; Rodríguez, L.; Quirante, J.; Messeguer, R.; Calvis, C.; Baldomá, L.; Badía, J. J. Organomet. Chem. 2013, 724, 289. (c) Budzisz, E.; Bobka, R.; Hauss, A.; Roedel, J. N.; Wirth, S.; Lorenz, I. P.; Rozalska, B.; Wieckowska-Szakiel, M.; Krajewskad, U.; Rozalskid, M. Dalton Trans. 2012, 41, 5925. (d) Campanella, N. C.; da Silva Demartini, M.; Torres, C.; Tonon de Almeida, E.; Cação Paiva Gouvêa, C. M. Genet. Mol. Biol. 2012, 35, 159. (e)

Quirante, J.; Ruiz, D.; González, A.; López, C.; Cascante, M.; Cortés, R.; Messeguer, R.; Calvis, C.; Baldomà, L.; Pascual, A.; Guérardel, Y.; Pradines, B.; Font-Bardía, M.; Calvet, T.; Biot, C. J. Inorg. Biochem. 2011, 105, 1720. (f) Subhas, M. S.; Racharlawar, S. S.; Sridhar, B.; Kennady, P. K.; Likhar, P. R.; Kantama, M. L.; Bhargavad, S. K. Org. Biomol. Chem. 2010, 8, 3001.

(6) Barry, N. P. E.; Sadler, P. J. Chem. Commun. 2013, 49, 5106 and references therein.

(7) Brown, S. D.; Trotter, K. D.; Sutcliffe, O. B.; Plumb, J. A.; Waddell, B.; Briggs, N.; Wheate, N. J. Dalton Trans. 2012, 41, 11330.

(8) (a) Adrio, L.; Antelo, J. M.; Ortigueira, J. M.; Fernández, J. J.; Fernández, A.; Pereira, M. T.; Vila, J. M. J. Organomet. Chem. 2009, 694, 1273. (b) Fernández, A.; López-Torres, M.; CastroJuiz, S.; Merino, M.; Vázquez-García, D.; Vila, J. M.; Fernández, J. J. Organometallics 2011, 30, 386. (c) Babić, D.; Ćurić, M.; Molčanov, K.; Ilc, G.; Plavec, J. Inorg. Chem. 2008, 47, 10446. (d) Molčanov, K.; Ćurić, M.; Babić, D.; Kojić-Prodić, B. J. Organomet. Chem. 2007, 692, 3874. (e) Cinčić, D.; Juribašić, M.; Babić, D.; Molčanov, K.; Šket, P.; J. Plavec, J.; Ćurić, M. Chem. Commun. 2011, 47, 11543. (f) Juribašić, M.; Ćurić, M.; Molčanov, K.; MatkovićČalogović, D.; Babić, D. Dalton Trans. 2010, 39, 8769. (g) Blackburn, O. A.; Coe, B. J.; Helliwell, M. Organometallics 2011, 30, 4910. (h) Bielsa, R.; Navarro, R.; Soler, T.; Urriolabeitia, E. P. Dalton Trans. 2008, 1787.

(9) (a) Sharma, V.; Khan, M. S. Y. Eur. J. Med. Chem. 2001, 36, 651. (b) Ünaleroğlu, C.; Temelli, B.; Hökelek, T. J. Mol. Struct. 2001, 570, 91. (c) Kise, N.; Oike, H.; Okazaki, E.; Yoshimoto, M.; Shono, T. J. Org. Chem. 1995, 60, 3980. (d) Liu, Y.; Wang, J. Appl. Organomet. Chem. 2009, 23, 476. (e) Andrez, J. C. Tetrahedron Lett. 2009, 50, 4225. (f) Komatsu, H.; Ochiai, B.; 
Hino, T.; Endo, T. J. Mol. Catal. A: Chem. 2007, 273, 289. (g) Billman, J. H.; Ho, J. Y. C.; Caswell, L. R. J. Org. Chem. 1957, 22 (5), 538.

(10) (a) Wild, S. B. Coord. Chem. Rev. 1997, 166, 291. (b) Slater, J. W.; Lydon, D. P.; Alcock, N. W.; Rouerke, J. P. Organometallics 2001, 20, 4418. (c) Herrmann, W. A.; Böhm, V. P. W.; Reisinger, C. P. J. Organomet. Chem. 1999, 576, 23.

(11) Albert, J.; Granell, J.; Moragas, R.; Sales, J.; Font-Bardia, M.; Solans, X. J. Organomet. Chem. $1995,494,95$.

(12) (a) Calmuschi, B.; Alesi, M.; Englert, U. Dalton Trans. 2004, 1852. (b) Braun, B.; Kalf, I.; Englert, U. Chem. Commun. 2011, 3846. (c) Falvello, L. R.; Fernández, S.; Navarro, R.; Pascual, I.; Urriolabeitia, E. P. J. Chem. Soc., Dalton Trans. 1997, 763.

(13) The destabilizing effect of two soft ligands in mutual trans positions has been called antisymbiosis; see: (a) Davies, J. A.; Hartley, F. R. Chem. Rev. 1981, 81, 79. (b) Pearson, R. G. Inorg. Chem. 1973, 12, 712. (c) Navarro, R.; Urriolabeitia, E. P. J. Chem. Soc., Dalton Trans. 1999,4111 . The term transphobia has been proposed to describe the difficulty of coordinating mutually trans phosphine and aryl ligands in palladium complexes; see: (d) Vicente, J.; Abad, J. A.; Frankland, A. D.; Ramírez de Arellano, M. C. Chem.-Eur. J. 1999, 5, 3066. (e) Vicente, J.; Arcas, A.; Bautista, D.; Jones, P. G. Organometallics 1997, 16, 2127. (f) Crespo, M.; Granell, J.; Solans, X.; Font-Bardia, M. J. Organomet. Chem. 2003, 681, 143.

(14) (a) Albert, J.; D’Andrea, L.; Granell, J.; Tavera, R.; Font-Bardia, M.; Solans, X. J. Organomet. Chem. 2007, 692, 3070. (b) Davies, D. L.; Al-Duaij, O.; Fawcett, J.; Singh, K. J. Organomet. Chem. 2008, 693, 965. (c) Bedford, R. B.; Cazin, C. S. J.; Coles, S. J.; Gelbrich, T.; Hursthouse, M. B.; Scordia, V. J. Dalton Trans. 2003, 3350. Vicente, J.; Saura-Llamas, I.; Jones, P. G. J. Chem. Soc., Dalton Trans. 1993, 3619.

(15) (a) Quiroga, A. G.; Cubo, L.; de Blas, E.; Aller, P.; Navarro-Ranninger, C. J. Inorg. Biochem. 2007, 101, 104. (b) Ramos-Lima, F. J.; Moneo, V.; Quiroga, A. G.; Carnero, A.; NavarroRanninger, C. Eur. J. Med. Chem. 2010, 45, 134. (c) Ramos-Lima, F. J.; Vrána, O.; Quiroga, A. G.; Navarro-Ranninger, C.; Halámiková, A.; Rybníčková, H.; Hejmalová, L.; Brabec, V. J. Med. 
Chem. 2006, 49, 2640. (d) Reedijk, J. Proc. Natl. Acad. Sci. U.S.A. 2003, 100, 3611 . (e) Ma, D.L.; Che, C.-M. Chem.-Eur. J. 2003, 9, 6133-6144.

(a) Reedijk, J. Platinum Met. Rev. 2008, 52, 2. (b) Vicente, J.; Arcas, A. Coord. Chem. Rev. $2005,249,1135-1154$.

725

(17) (a) Kalaivani, P.; Prabhakaran, R.; Dallemer, F.; Poornima, P.; Vaishnavi, E.; Ramachandran, E.; Padma Vijaya, V.; Renganathand, R.; Natarajan, K. Metallomics 2012, 4, 101-113. (b) Mazumder, M. E. H.; Beale, P.; Chan, C.; Yu, J. Q.; Huq, F. ChemMedChem. 2012, 7, 1840-1846. (c) H. Cheng, H.; Huq, F.; Beale, P.; Fisher, K. Eur. J. Med. Chem. 2006, 41, 896-903.

Cortés, R.; Crespo, M.; Davin, L.; Martín, R.; Quirante, J.; Ruiz, D.; Messeguer, R.; Calvis, C.; Baldomà, L.; Badia, J.; Font-Bardía, M.; Calvet, T.; Cascante, M. Eur. J. Med. Chem. 2012, 557.

(19) Snyder, R. D.; McNulty, J.; Zairov, G.; Ewing, D. E.; Hendry, L. B. Mutat. Res., Fundam. Mol. Mech. Mutagen. 2005, 1-2, 88.

(20) Sappal, D. S.; McClendon, A. K.; Fleming, J. A.; Thoroddsen, V.; Connolly, K.; Reimer, C.; Blackman, R. K.; Bulawa, C. E.; Osheroff, N.; Charlton, P.; Rudolph-Owen, L. A. Mol. Cancer Ther. 2004, 3, 47.

(21) Palchaudhuri, R.; Hergenrother, P. J. Curr. Opin. Biotechnol. 2007, 18, 497.

(22) Perrin, D. D.; Armarego, W. L. F. Purification of Laboratory Chemicals, 5th ed.; ButterworthHeinemann: Oxford, UK, 2002.

(23) Sheldrick, G. M. SHELXS, a Program for Automatic Solution of Crystal Structure; University of Göttingen: Göttingen, Germany, 1997.

(24) Sheldrick, G. M. SHELXS97, a Computer Program for Crystal Structure Refinement; University of Göttingen: Göttingen, Germany, 1997.

(25) Givens, K. T.; Kitada, S.; Chen, A. K.; Rothschiller, J.; Lee, D. A. Investig. Ophthalmol. Vis. Sci. 1990, 31, 1856.

(26) Abdullah, A.; Huq, F.; Chowdhury, A.; Tayyem, H.; Beale, P.; Fisher, K. BMC Chem. Biol. $2006,6,3$. 
(27) Allinger, N. L.; Yuh, Y. H.; Lii, J. H. J. Am. Chem. Soc. 1989, 111, 8551.

(28) Shim, J. Y.; Bowen, J. P. J. Comput. Chem. 1998, 19, 1370.

751

(29) Quantum Cache, Version 7.5.0.85; Fujitsu Limited: Sunnyvale, CA, USA, 2006.

752

(30) Frisch, M. J.; Trucks, G. W.; Schlegel, H. B.; Scuseria, G. E.; Robb, M. A.; Cheeseman, J. R.;

Montgomery, J. A., Jr.; Vreven, T.; Kudin, K. N.; Burant, J. C.; Millam, J. M.; Iyengar, S. S.;

Stewart, J. J. P. J. Mol. Model. 2007, 13, 1173.

Tomasi, J.; Barone, V.; Mennucci, B.; Cossi, M.; Scalmani, G.; Rega, N.; Petersson, G. A.;

Nakatsuji, H.; Hada, M.; Ehara, M.; Toyota, K.; Fukuda, R.; Hasegawa, J.; Ishida, M.;

Nakajima, T.; Honda, Y.; Kitao, O.; Nakai, H.; Klene, M.; Li, X.; Knox, J. E.; Hratchian, H. P.;

Cross, J. B.; Bakken, V.; Adamo, C.; Jaramillo, J.; Gomperts, R.; Stratmann, R. E.; Yazyev, O.;

Austin, A. J.; Cammi, R.; Pomelli, C.; Ochterski, J. W.; Ayala, P. Y.; Morokuma, K.; Voth, G.

A.; Salvador, P.; Dannenberg, J. J.; Zakrzewski, V. G.; Dapprich, S.; Daniels, A. D.; Strain, M.

C.; Farkas, O.; Malick, D. K.; Rabuck, A. D.; Raghavachari, K.; Foresman, J. B.; Ortiz, J. V.;

Cui, Q.; Baboul, A. G.; Clifford, S.; Cioslowski, J.; Stefanov, B. B.; Liu, G.; Liashenko, A.;

Piskorz, P.; Komaromi, I.; Martin, R. L.; Fox, D. J.; Keith, T.; Al-Laham, M. A.; Peng, C. Y.;

Nanayakkara, A.; Challacombe, M.; Gill, P. M. W.; Johnson, B.; Chen, W.; Wong, M. W.;

González, C.; Pople, J. A. Gaussian 03, Revision C.02; Gaussian, Inc.: Wallingford, CT, USA, 2004

(31) Becke, A. D. J. Chem. Phys. 1993, 98, 5648.

(32) Lee, C.; Yang, W.; Parr, R. G. Phys. Rev. B 1988, 37, 785.

(33) Wadt, W. R.; Hay, P. J. J. Chem. Phys. 1985, 82, 284.

(34) Hay, P. J.; Wadt, W. R. J. Chem. Phys. 1985, 82, 299.

(35) Hehre, W. J.; Ditchfield, R.; Pople, J. A. J. Chem. Phys. 1972, 56, 2257.

(36) Hariharan, P. C.; Pople, P. A. Theor. Chim. Acta 1973, 28, 213.

(39) Spartan '14, version 1.1.0; Wavefunction Inc.: Irvine, CA, USA, 2013. 
Chart 1 Structural Formula of BBR3464

779

780

Figure 1. Molecular crystal structure of $1 \mathrm{~d} \cdot 3(\mathrm{CDCl} 3)$. Hydrogen and deuterium atoms have been omitted for clarity. Selected bond lengths $(\AA)$ and bond angles $(\mathrm{deg})$ : $\operatorname{Pd}(1)-C(1)=1.998(4)$,

$\mathrm{Pd}(1)-\mathrm{N}(1)=2.029(5), \mathrm{Pd}(1)-\mathrm{N}(2)=2.046(5), \mathrm{Pd}(1)-\mathrm{Cl}(1)=2.4099(14), \mathrm{N}(1)-\mathrm{C}(7)=1.276(7)$, $\mathrm{C}(1)-\mathrm{Pd}(1)-\mathrm{N}(1)=80.74(18), \mathrm{N}(1)-\mathrm{Pd}(1)-\mathrm{Cl}(1)=96.39(13), \mathrm{Cl}(1)-\mathrm{Pd}(1)-\mathrm{N}(2)=88.76(11)$,

$\mathrm{N}(2)-\mathrm{Pd}(1)-\mathrm{C}(1)=94.38(16)$.

Figure 2. Molecular crystal structure of $2 \mathrm{~d} \cdot 2(\mathrm{CDCl} 3)$. Hydrogen and deuterium atoms have been omitted for clarity. Selected bond lengths $(\AA)$ and bond angles (deg): $\operatorname{Pd}(1)-C(1)=2.008(5)$,

$\mathrm{Pd}(1)-\mathrm{N}(1)=2.034(4), \operatorname{Pd}(1)-\mathrm{N}(2)=2.052(4), \operatorname{Pd}(1)-\mathrm{Cl}(1)=2.4099(16), \mathrm{N}(1)-\mathrm{C}(7)=1.297(7)$,

$\mathrm{C}(1)-\mathrm{Pd}(1)-\mathrm{N}(1)=82.3(2), \mathrm{N}(1)-\mathrm{Pd}(1)-\mathrm{Cl}(1)=95.59(14), \mathrm{Cl}(1)-\mathrm{Pd}(1)-\mathrm{N}(2)=88.96(12)$,

790

$\mathrm{N}(2)-\mathrm{Pd}(1)-\mathrm{C}(1)=93.17(18)$.

791

792

Figure 3. Molecular crystal structure of $1 \mathrm{e} \cdot 4(\mathrm{CDCl} 3)$. Hydrogen atoms have been omitted for clarity.

Selected bond lengths $(\AA)$ and bond angles $(\mathrm{deg}): \operatorname{Pd}(1)-\mathrm{C}(1)=2.065(4), \operatorname{Pd}(1)-\mathrm{N}(1)=2.127(3)$, $\mathrm{Pd}(1)-\mathrm{P}(1)=2.2833(12), \mathrm{Pd}(1)-\mathrm{Cl}(1)=2.3779(17), \mathrm{N}(1)-\mathrm{C}(7)=1.222(5), \mathrm{C}(1)-\mathrm{Pd}(1)-\mathrm{N}(1)=$ 80.44(14), $\mathrm{N}(1)-\mathrm{Pd}(1)-\mathrm{Cl}(1)=91.68(9), \mathrm{Cl}(1)-\mathrm{Pd}(1)-\mathrm{P}(1)=93.42(5), \mathrm{P}(1)-\mathrm{Pd}(1)-\mathrm{C}(1)=94.49(12)$.

796

Chart 2. Proposed Structure for Compound $3 \mathrm{f}$ and Labeling of the Protons

798

799

Figure 4. DFT-optimized structure for the dinuclear form of compound $3 \mathrm{f}$.

800

Figure 5. DFT-optimized structure for the tetranuclear form of compound $3 \mathrm{f}$.

802

Figure 6. Inhibition of cell growth proliferation for human adenocarcinoma colon (HCT116) and breast (MDA-MB231 and MCF7) cell lines after $72 \mathrm{~h}$ of exposure to compounds 3a, 3b, 3e, and $3 \mathrm{f}$ and cisplatin.

806

807

Figure 7. 7. Interaction of pBluescript $\mathrm{SK}+$ plasmid DNA $(0.8 \mu \mathrm{g})$ with increasing concentrations of compounds 1a, 1b, 1e, 3a, 3b, 3e, 3f, cisplatin, and ethidium bromide (EtBr). Lane 1: DNA only. Lane 2: $2.5 \mu \mathrm{M}$. Lane 3: $5 \mu \mathrm{M}$. Lane 4: $10 \mu \mathrm{M}$. Lane 5: $25 \mu \mathrm{M}$. Lane 6: $50 \mu \mathrm{M}$. Lane 7: $100 \mu \mathrm{M}$. Lane 8: 200 
813 Figure 8. Analysis of $3 \mathrm{e}$ as a putative DNA intercalator or topoisomerase I inhibitor. Conversion of

814 supercoiled pBluescript plasmid DNA $(0.8 \mu \mathrm{g})$ to relaxed DNA by the action of topoisomerase I (3

815 units) in the absence or in the presence of increasing amounts of compound 3e was analyzed by agarose

816 gel electrophoresis. Negative and positive intercalator controls, etoposide (Etop, $100 \mu \mathrm{M}$ ) and ethidium

817 bromide $(\mathrm{EtBr}, 10 \mu \mathrm{M})$, are also shown. Lane 1, DNA only. Lane 2, $0 \mu \mathrm{M}$ compound. Lane 3, $10 \mu \mathrm{M}$.

818 Lane 4, $25 \mu \mathrm{M}$. Lane 5, $50 \mu \mathrm{M}$. Lane 6, $100 \mu \mathrm{M}$. Lane 7, $200 \mu \mathrm{M}$. Except for lane 1, all lanes included

819 topomerase I. $\mathrm{ccc}=$ supercoiled closed circular DNA form. Oc $=$ open circular DNA form.

820

821 
<smiles>N[P](N)(NCCCCCCN[PH](N)(N)Cl)NCCCCCCN[PH](N)(N)Cl</smiles> 


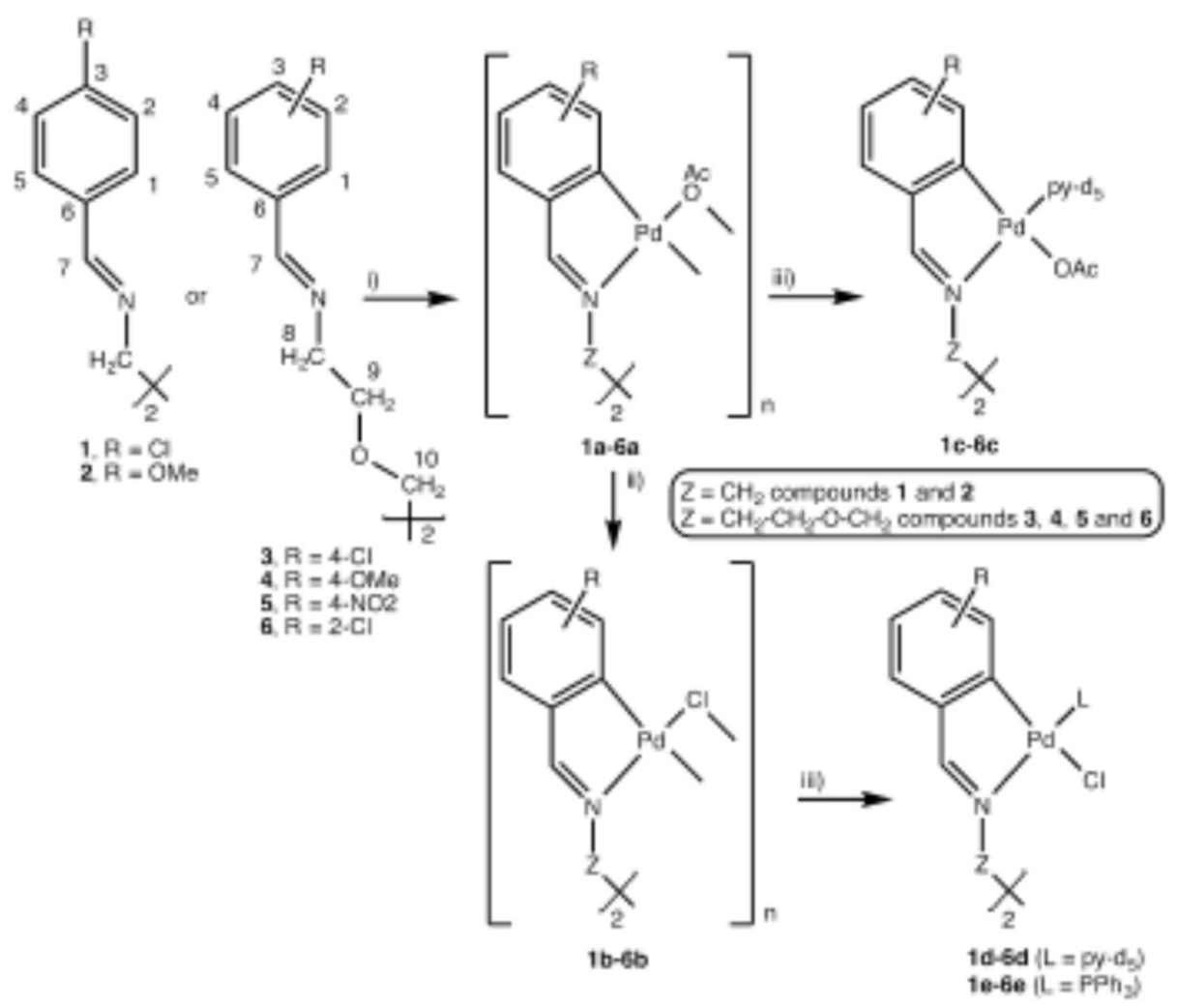

a Conditions: (i) $\mathrm{Pd}(\mathrm{OAc}) 2$, toluene, $60^{\circ} \mathrm{C}$ for 1a, 2a, and 3a; $\mathrm{Pd}(\mathrm{OAc}) 2$, acetic acid, $60{ }^{\circ} \mathrm{C}$ for $4 \mathrm{a}$ and $5 \mathrm{a} ; \mathrm{Pd}(\mathrm{OAc}) 2$, acetic acid, room temperature for $6 \mathrm{a}$. (ii) $\mathrm{LiCl}$ (excess), acetone, or a mixture of chloroform/acetone, room temperature. (iii) $\mathrm{L}=$ py-d5: py-d5, $\mathrm{CDCl}$, room temperature, $\mathrm{L}=\mathrm{PPh} 3$ : molar ratio $\mathrm{PPh} 3 / \mathrm{b}(\mathrm{n}=1)=2: 1$, acetone or chloroform, room temperature 
842

843
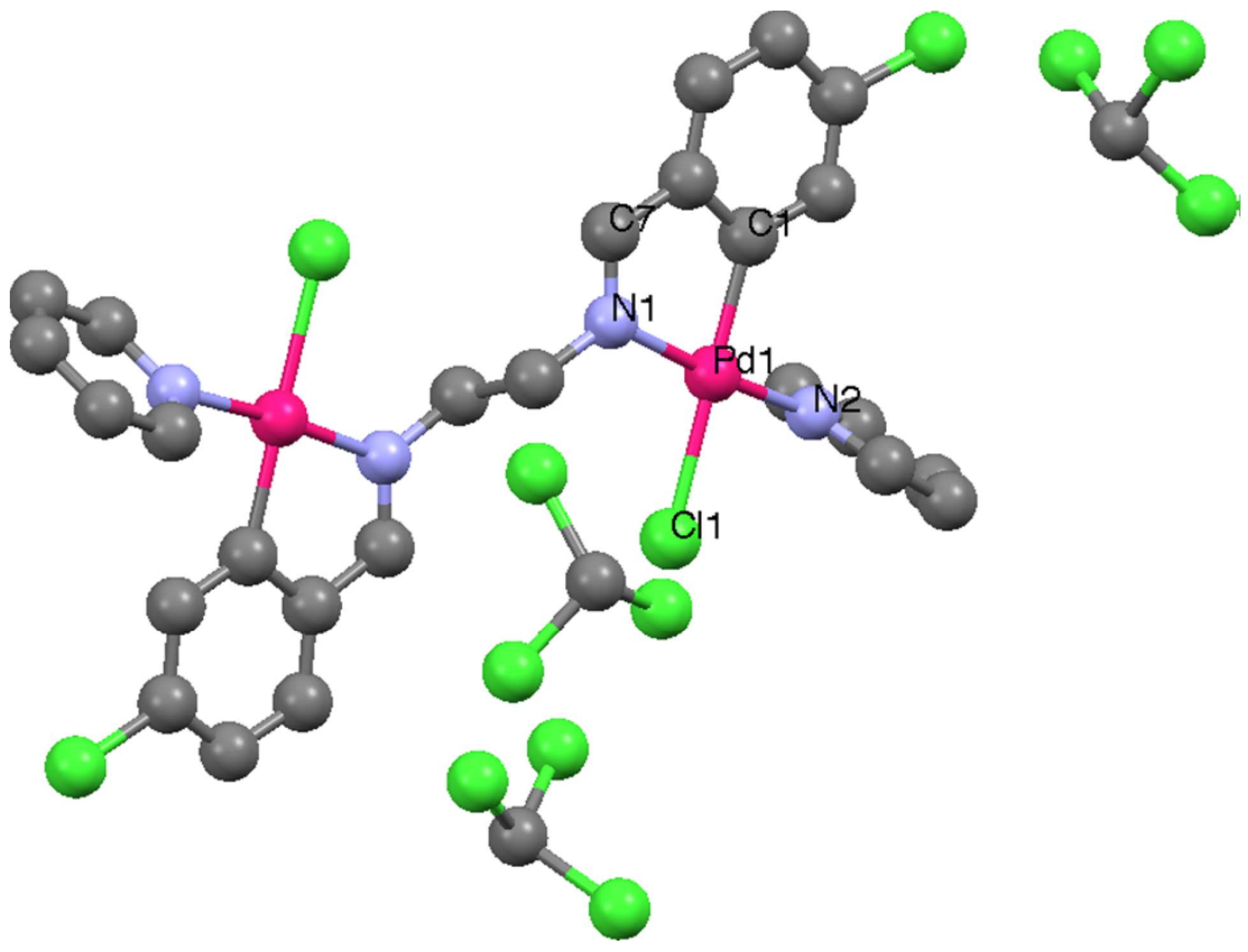


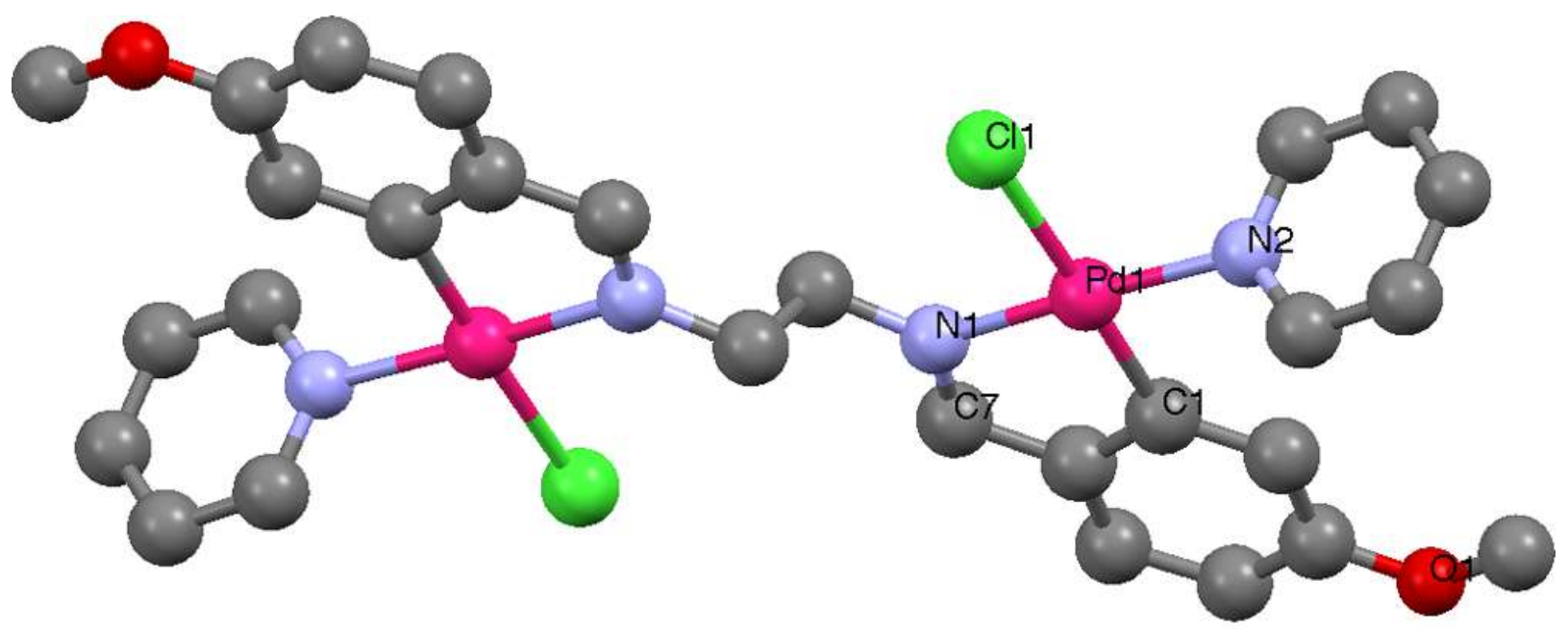

849

850

851

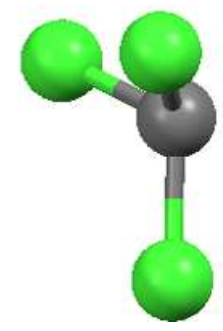


853

854

855

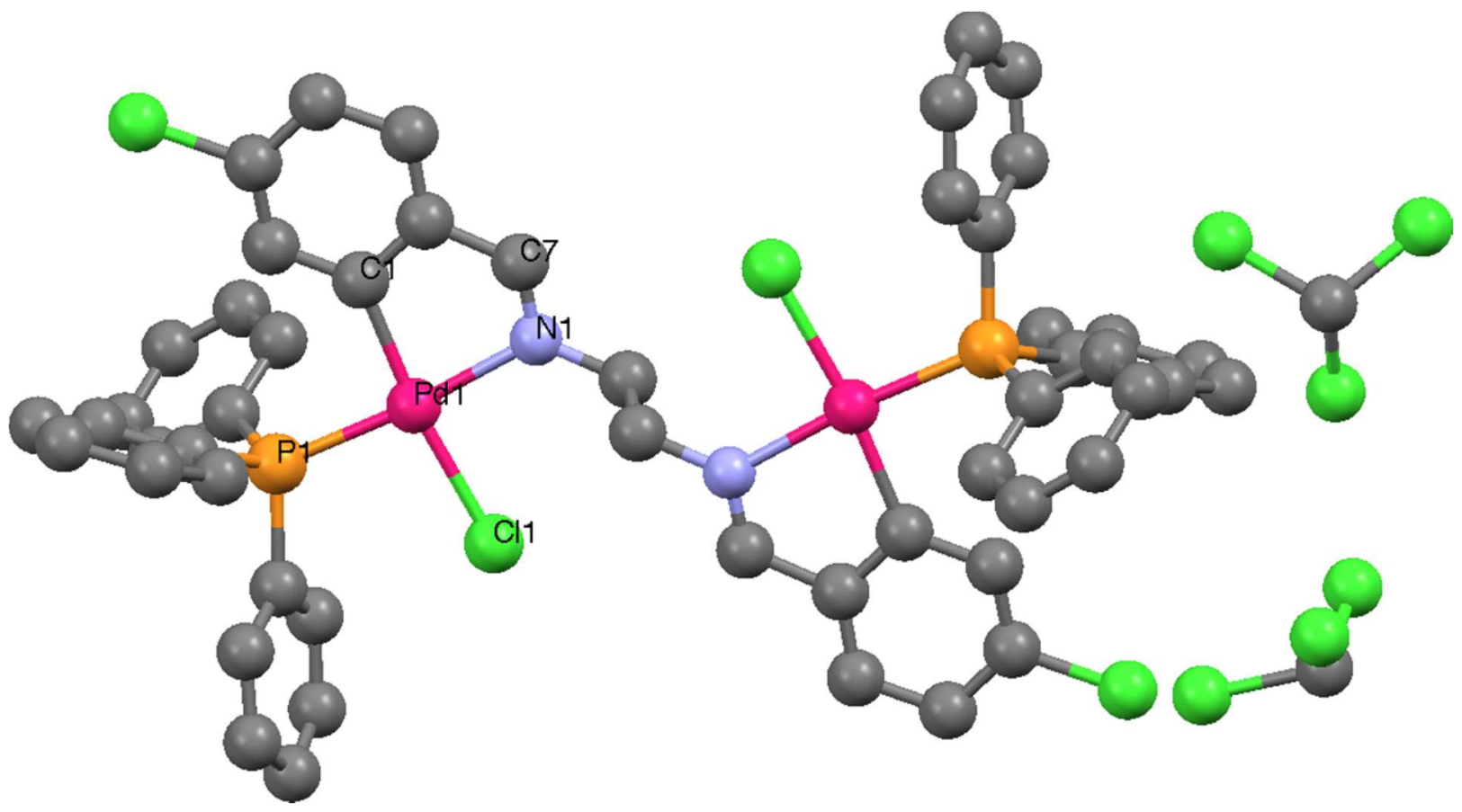

856 


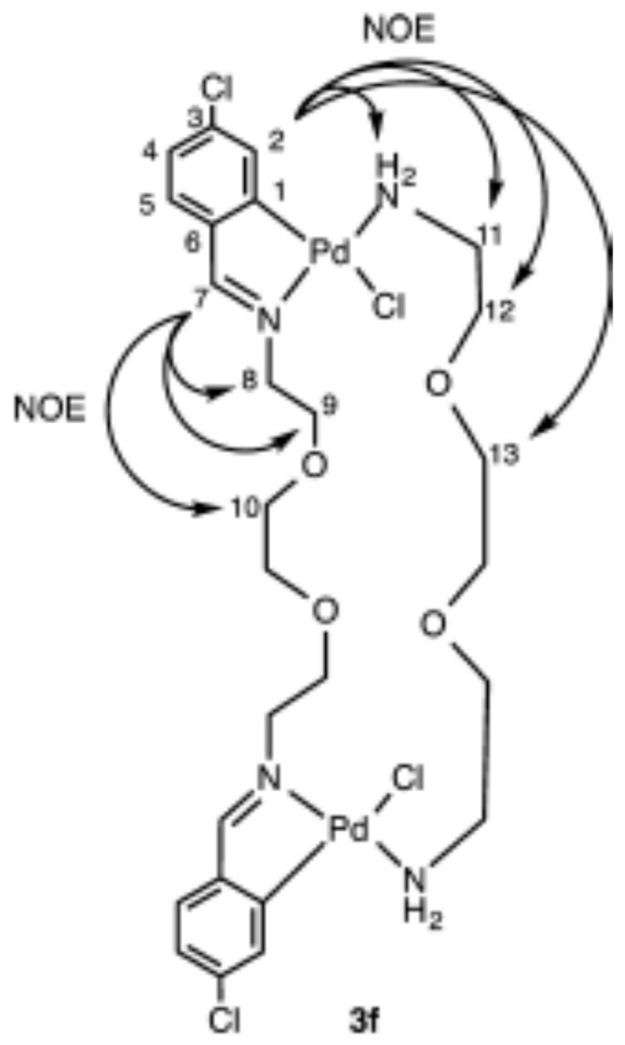

861

862 


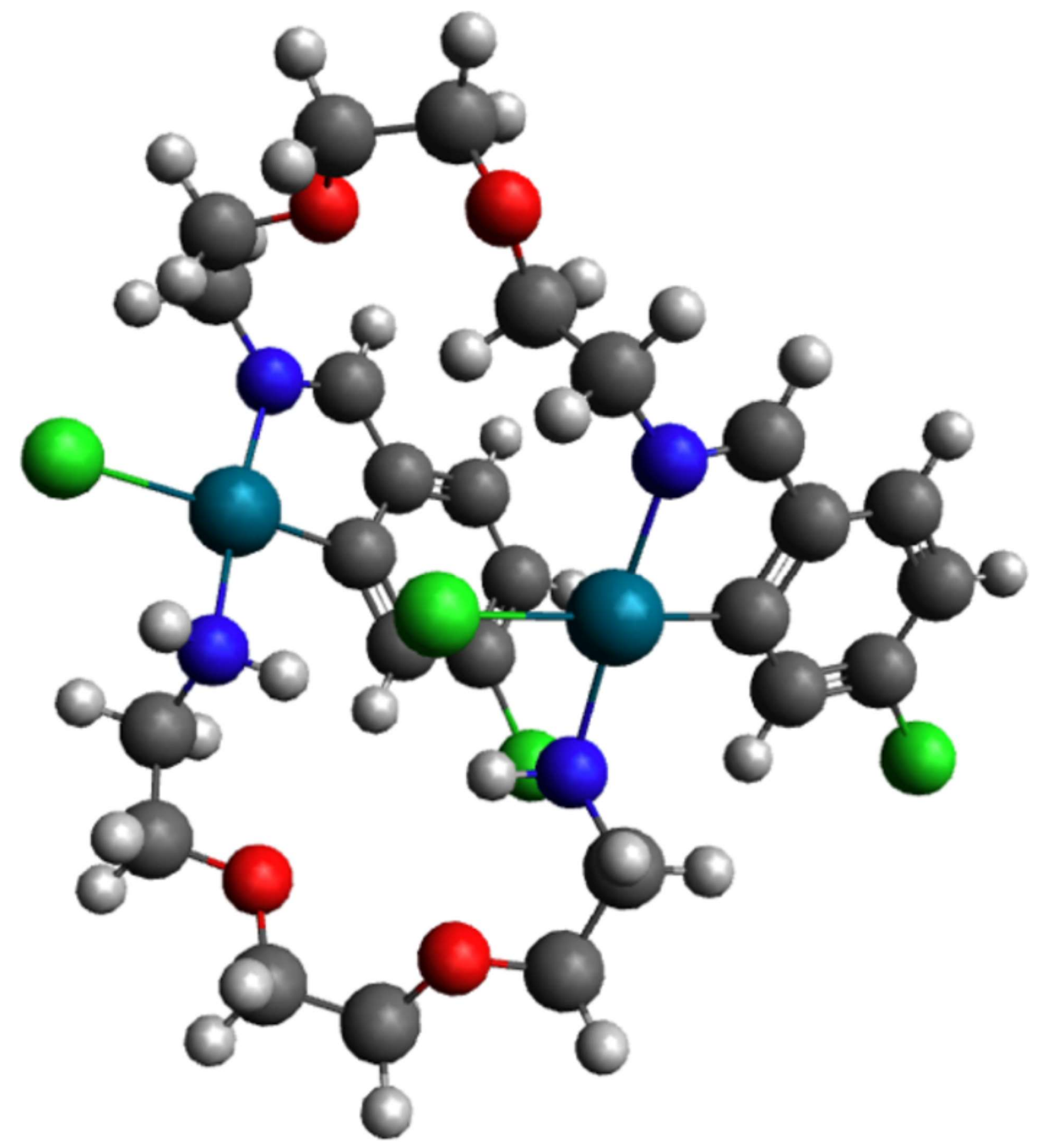

866

867 
FIGURE 5

869

870

871

872

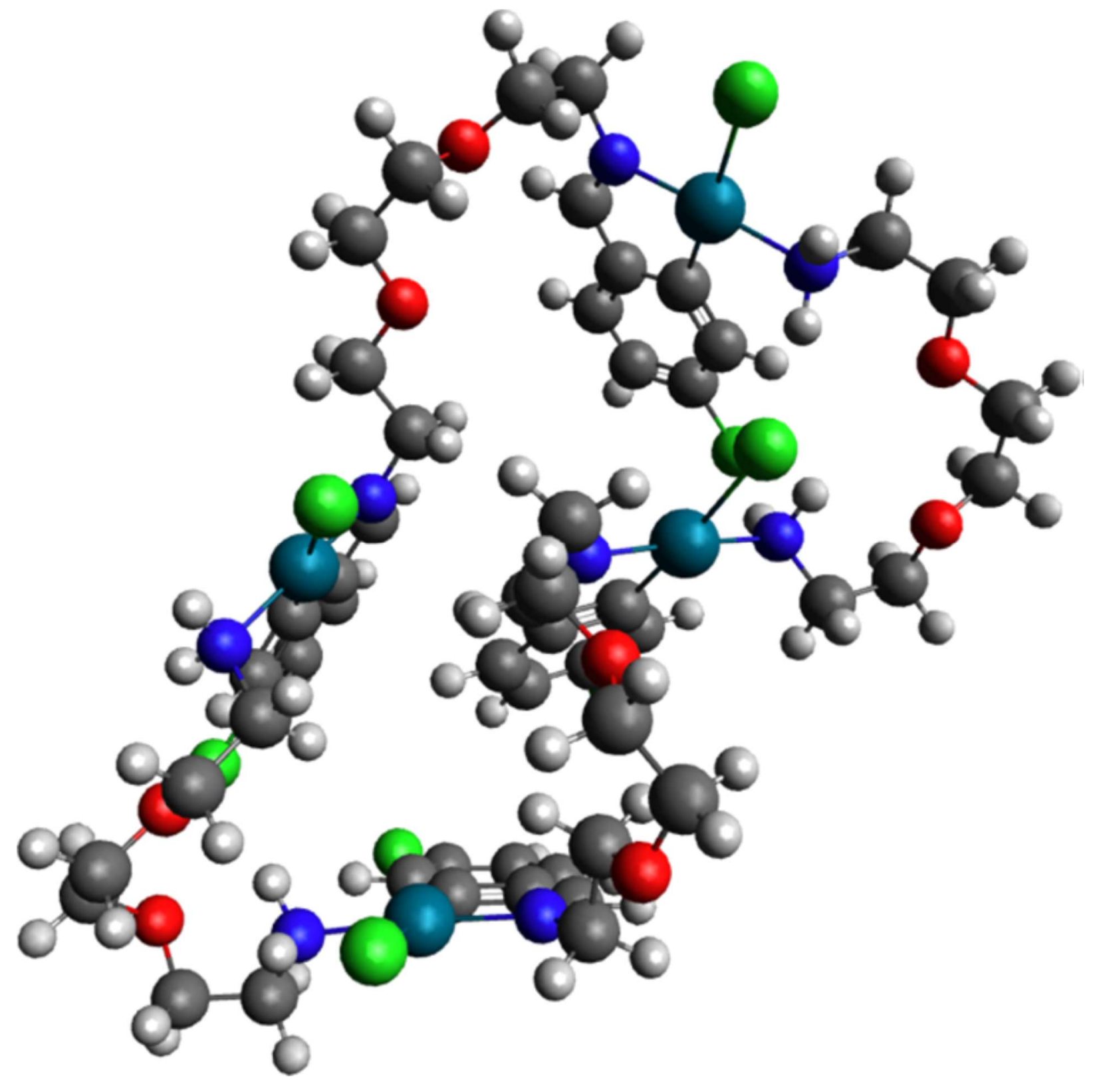



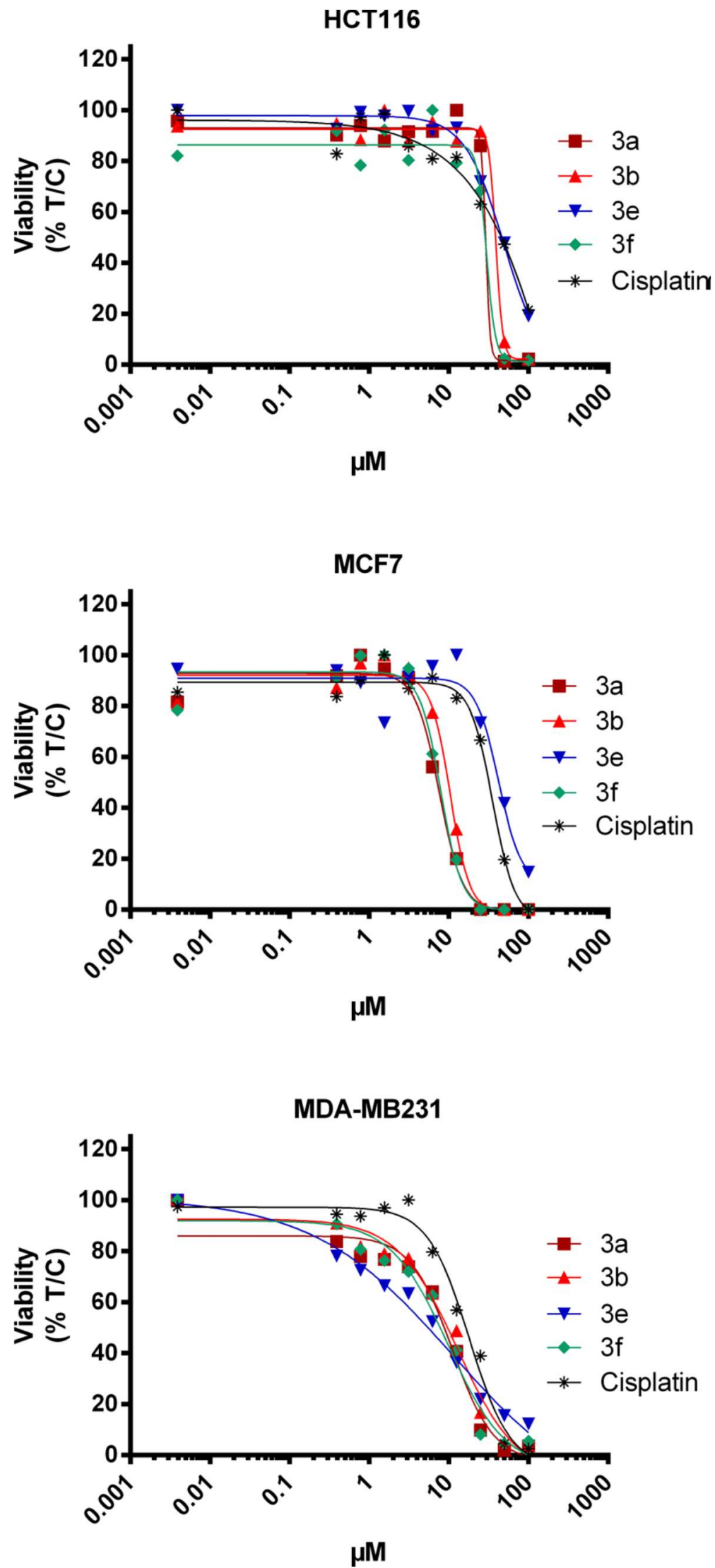
879
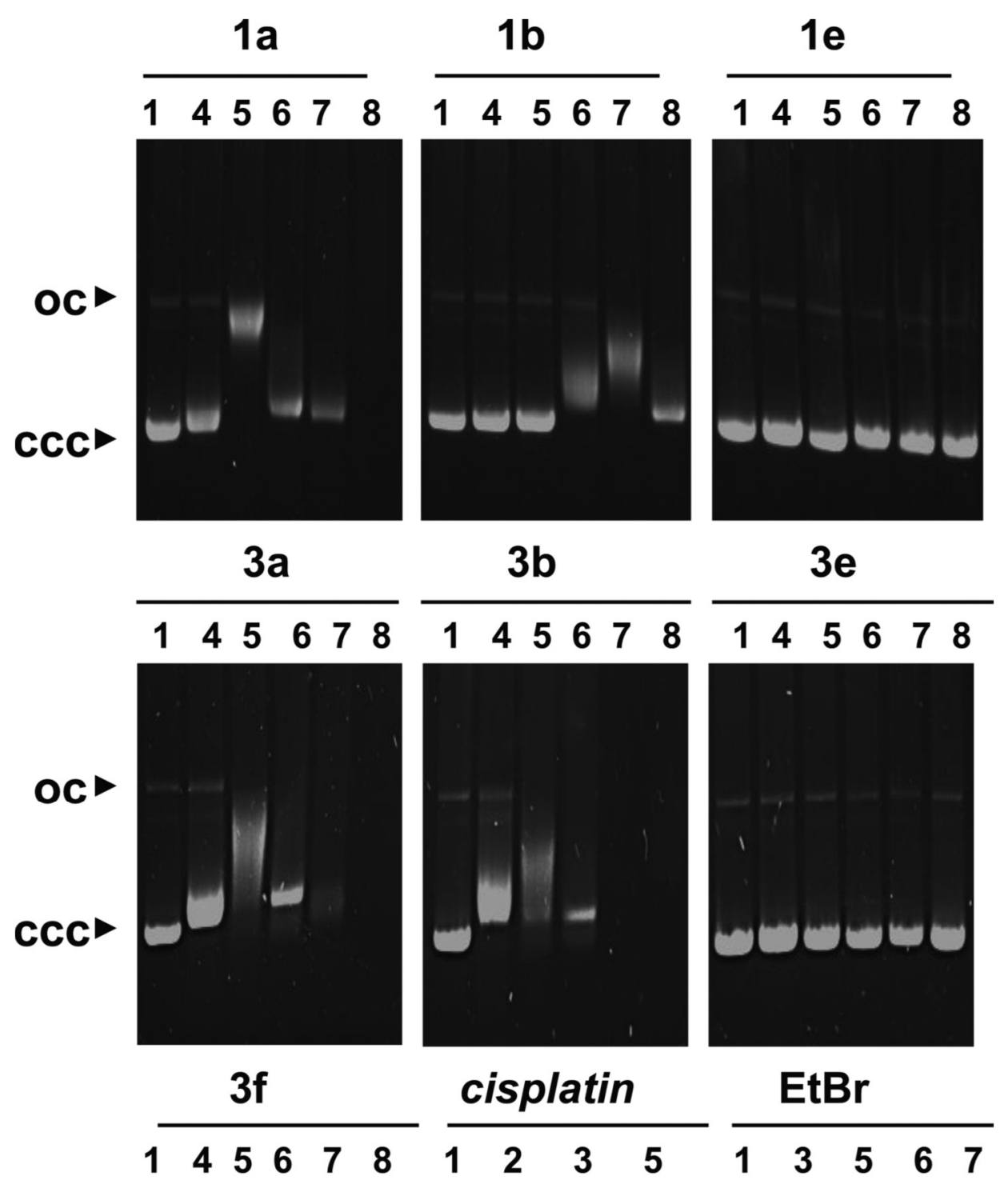


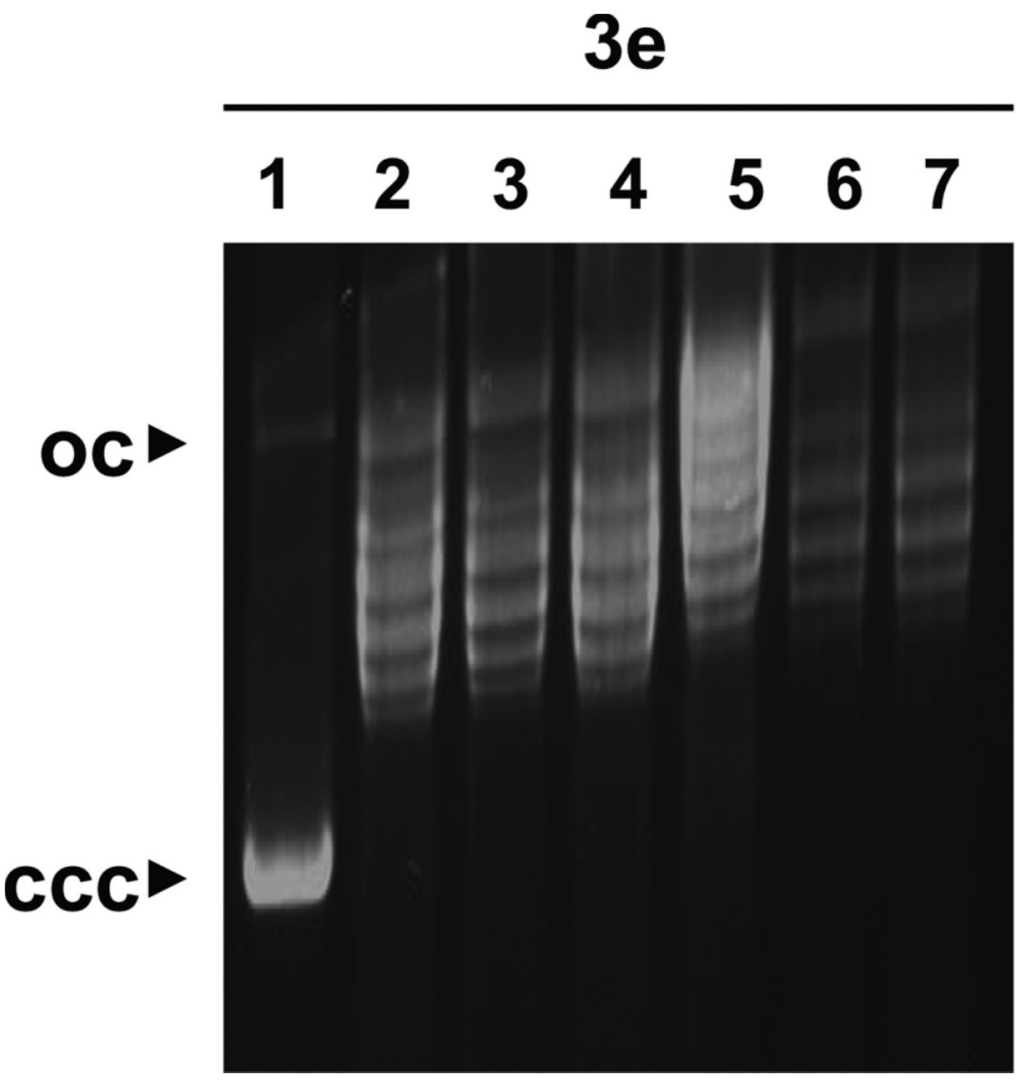

Etop EtBr

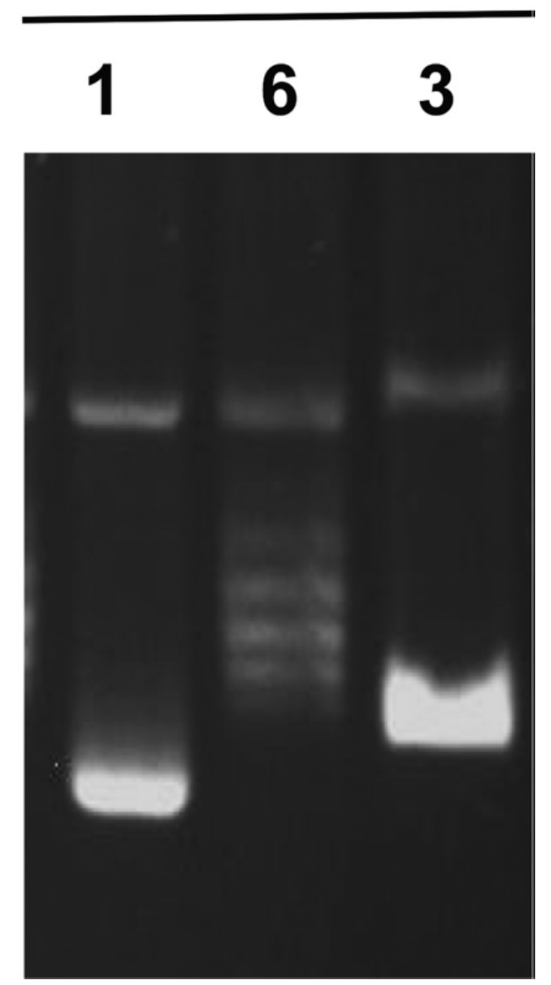


887 Table 1. IC50 $(\mu \mathrm{M})$ for Compounds 1a, 1b, 1e, 3a, 3b, 3e, 3f, and Cisplatina 888

\begin{tabular}{|c|c|c|c|}
\hline & \multicolumn{3}{|c|}{$I C_{v}(\mu \mathrm{M})$} \\
\hline & HCT116 & MCF7 & MDA-MB231 \\
\hline 1 & $>100$ & $>100$ & $>100$ \\
\hline 14 & $>100$ & $>100$ & $>100$ \\
\hline lb & $>100$ & $>100$ & $>100$ \\
\hline le & $>100$ & $>100$ & $>100$ \\
\hline 3 & $>100$ & $>100$ & $>100$ \\
\hline $3 \mathrm{a}$ & $29 \pm$ nd & $5.2 \pm 0.6$ & $8.8 \pm 26$ \\
\hline $3 b$ & $39 \pm 11$ & $6.7 \pm 0.5$ & $9.6 \pm 5.2$ \\
\hline $3 e$ & $47 \pm 19$ & 25 = nd & $5.5 \pm 8.3$ \\
\hline $3 f$ & $30=9$ & $5.5 \pm 0.5$ & $7.8 \pm 3$ \\
\hline displat in ${ }^{2}$ & $40=4.4$ & $19 \pm 4.5$ & $6.5 \pm 24$ \\
\hline
\end{tabular}

aData are shown as the mean values of two experiments performed in triplicate with the corresponding standard deviation. "bis. $\left[\mathrm{PtCl}_{2}\left(\mathrm{NH}_{3}\right)_{2}\right]$ is taken as reference compound. 